Supporting Information for:

\title{
Unravelling Molecular Aspects of the Migratory Insertion Step in Cp*Co"l' Metallacyclic Systems
}

\author{
Jesús Sanjosé-Orduna, Jordi Benet-Buchholz, Mónica H. Pérez-Temprano* \\ Institute of Chemical Research of Catalonia (ICIQ), Barcelona Institute of Science and \\ Technology, Av. Països Catalans 16, 43007 Tarragona, Spain \\ E-mail: mperez@iciq.es \\ Table of Contents
}

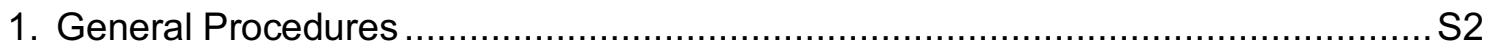

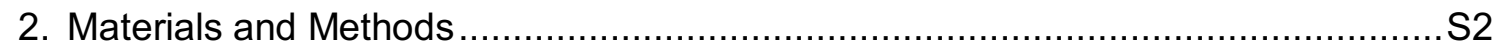

3. Procedure for the Synthesis of Inserted Cobaltacycles

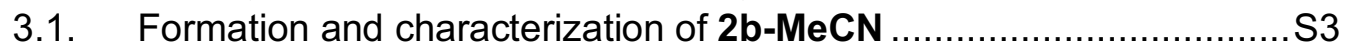

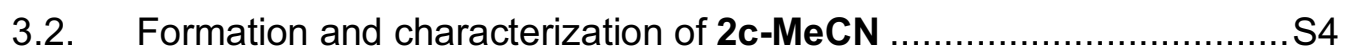

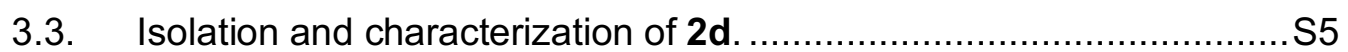

4. Mechanistic study on the insertion reaction using dpa as model coupling partner

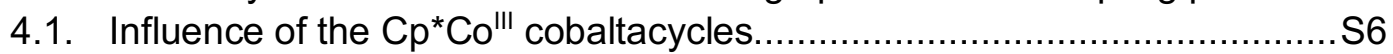

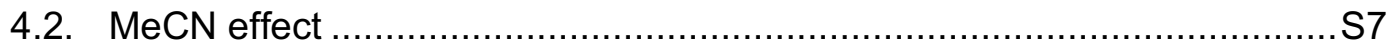

4.3. Influence of diphenylacetylene

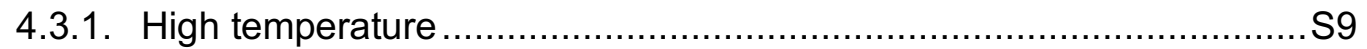

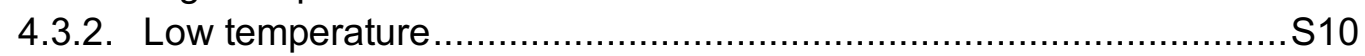

4.4. Eyring analysis of dpa insertion at low temperature ...............................S12

5. Reaction of $1-\mathrm{MeCN}$ with terminal unsaturated electrophiles

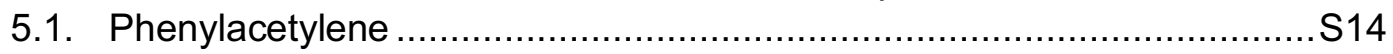

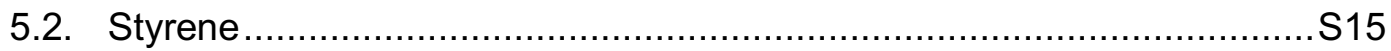

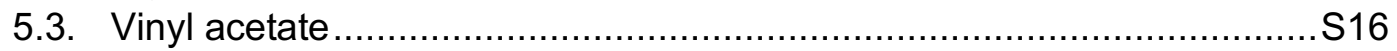

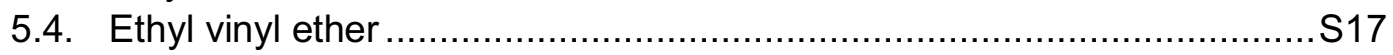

6. Single Crystal X-Ray Structure Determinations .................................................. 18

7. NMR spectra

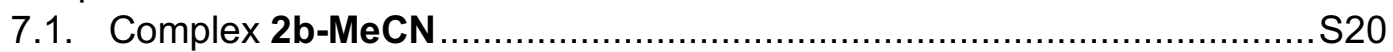

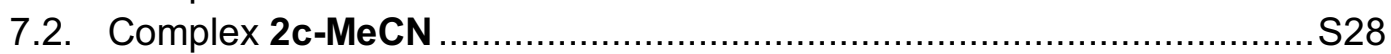

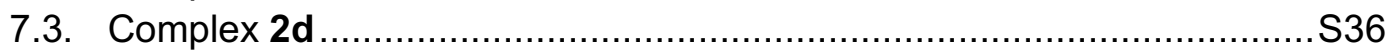




\section{General Procedures}

All experiments were conducted under an argon-filled glove box (mBraun Unilab 4420) with concentrations of $\mathrm{O}_{2}$ and $\mathrm{H}_{2} \mathrm{O}<0.1$ ppm or using Schlenk techniques under argon atmosphere. All the glassware was oven-dried at $100^{\circ} \mathrm{C}$ overnight and cooled under vacuum prior use. NMR spectra were obtained on a Bruker $400 \mathrm{MHz}$ or a $500 \mathrm{MHz}$ cryoprobe spectrometers. ${ }^{1} \mathrm{H},{ }^{13} \mathrm{C}$ and ${ }^{19} \mathrm{~F}$ NMR chemical shifts are reported in parts per million (ppm), relative to tetramethylsilane (TMS) for ${ }^{1} \mathrm{H}$ and ${ }^{13} \mathrm{C}$ with the residual solvent peak used as an internal reference, and relative to $\mathrm{CCl}_{3} \mathrm{~F}$ (Freon) for ${ }^{19} \mathrm{~F}$. Multiplicities are reported as follows: singlet (s), doublet (d), doublet of doublets (dd), triplet of doublets $(\mathrm{td})$, triplet $(\mathrm{t})$, and multiplet $(\mathrm{m})$. High Resolution Mass Spectrometry (HRMS) data was recorded on a LCT-Premier (Waters) or a MicroTOF Focus (Bruker Daltonics) mass spectrometers using ESI ionization technique and acetonitrile as solvent. Details for $\mathrm{X}$ ray structure determination can be found on page $\mathrm{S} 18$.

\section{Materials and Methods}

Commercially available reagents diphenylacetylene, phenylacetylene, vinyl acetate, ethyl vinyl ether, $\mathrm{AgBF}_{4}$, were used without further purification directly as received from the commercial supplier, and stored under inert gas and/or low temperature when required. The solvents ( $n$-hexane, $\mathrm{Et}_{2} \mathrm{O}, \mathrm{CH}_{2} \mathrm{Cl}_{2}, \mathrm{MeCN}$ ) were used from a solvent purification system pure-solv (SPS-400, Innovative Technology) and stored under argon with activated $4 \AA$ molecular sieves.

Deuterated solvents $\left(\mathrm{CD}_{3} \mathrm{CN}, \mathrm{CD}_{2} \mathrm{Cl}_{2}\right)$ were stored under argon with activated $4 \AA$ molecular sieves.

1-MeCN was synthesized according to previous literature procedures. ${ }^{1}$

\footnotetext{
1 J. Sanjosé-Orduna, D. Gallego, A. Garcia-Roca, E. Martin, J. Benet-Buchholz, M. H. PérezTemprano, Angew. Chem. Int. Ed. 2017, 56, 12137.
} 


\section{Procedure for the Synthesis of Inserted Cobaltacycles}

\subsection{Formation and characterization of $2 \mathrm{~b}-\mathrm{MeCN}$}

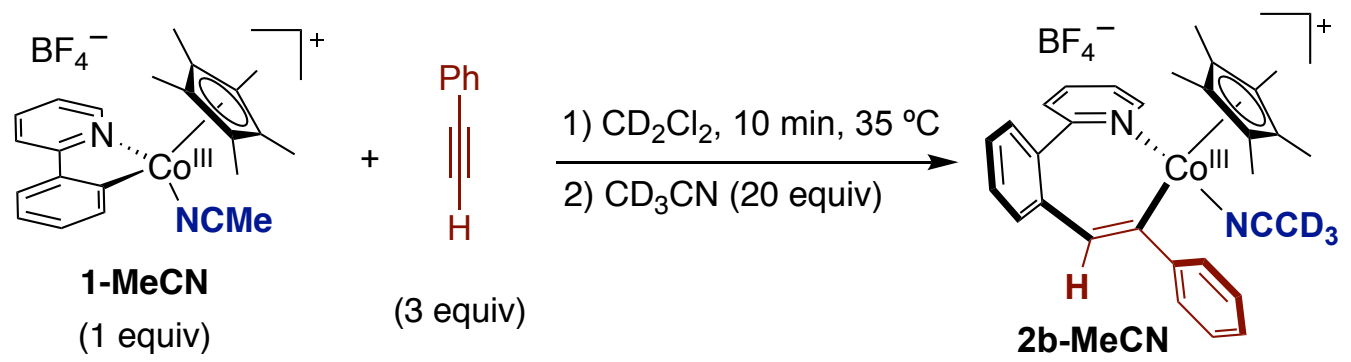

Inside the glovebox a NMR tube was loaded with 1-MeCN (4.7 mg, $0.01 \mathrm{mmol})$. The tube was then taken out and connected to the Schlenk line via an adaptor and then the solid was dissolved in $0.5 \mathrm{~mL}$ of $\mathrm{CD}_{2} \mathrm{Cl}_{2}$. After that, phenylacetylene $(3.3 \mu \mathrm{L}, 0.03 \mathrm{mmol})$ was added. After $10 \mathrm{~min}$ at $35^{\circ} \mathrm{C}$, excess of $\mathrm{CD}_{3} \mathrm{CN}(10 \mu \mathrm{L}, 0.19 \mathrm{mmol})$ was added to stabilize this reactive intermediate. Full characterization of this mixture by NMR was performed afterwards.

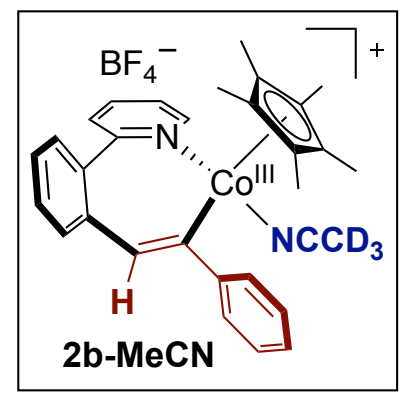

${ }^{1} \mathrm{H}$ NMR $\left(500 \mathrm{MHz}, \mathrm{CD}_{2} \mathrm{Cl}_{2} / \mathrm{CD}_{3} \mathrm{CN}(50: 1), 25^{\circ} \mathrm{C}\right): \delta 9.10(\mathrm{~d}, \mathrm{~J}=4.9 \mathrm{~Hz}, 1 \mathrm{H}), 7.91(\mathrm{t}, \mathrm{J}=7.6 \mathrm{~Hz}$, $1 \mathrm{H}), 7.53-7.46(\mathrm{~m}, 5 \mathrm{H}), 7.21(\mathrm{t}, \mathrm{J}=7.4 \mathrm{~Hz}, 2 \mathrm{H}), 7.16(\mathrm{~d}, \mathrm{~J}=7.3 \mathrm{~Hz}, 1 \mathrm{H}), 7.06(\mathrm{~s}, 1 \mathrm{H}), 6.94(\mathrm{~d}$, $\mathrm{J}=7.2 \mathrm{~Hz}, 2 \mathrm{H}), 1.97(\mathrm{~s}, 3 \mathrm{H}), 1.02(\mathrm{~s}, 15 \mathrm{H})$. One proton is missing due to overlapping peaks.

${ }^{13} \mathrm{C}$ NMR (126 MHz, $\left.\mathrm{CD}_{2} \mathrm{Cl}_{2} / \mathrm{CD}_{3} \mathrm{CN}(50: 1), 2{ }^{\circ} \mathrm{C}\right) \delta 167.54,165.84,155.23,154.64,139.94$, 138.82 , 135.66, 135.35, 133.89, 132.20, 129.93, 129.56, 129.25, 127.91, 127.09, 126.46, 125.60, $124.78,122.44,96.73,9.54$.

$\left.{ }^{19} \mathrm{~F} \mathrm{NMR} \mathrm{(376} \mathrm{MHz,} \mathrm{CD}_{2} \mathrm{Cl}_{2} / \mathrm{CD}_{3} \mathrm{CN}(50: 1), 25^{\circ} \mathrm{C}\right): \delta-152.16$ (s).

HRMS-ESI (m/z): [M-MeCN] ${ }^{+}$calcd for $\mathrm{C}_{29} \mathrm{H}_{29} \mathrm{CoN}, 450.1632$; Found, 450.1629. 


\subsection{Formation and characterization of $2 \mathrm{c}-\mathrm{MeCN}$}
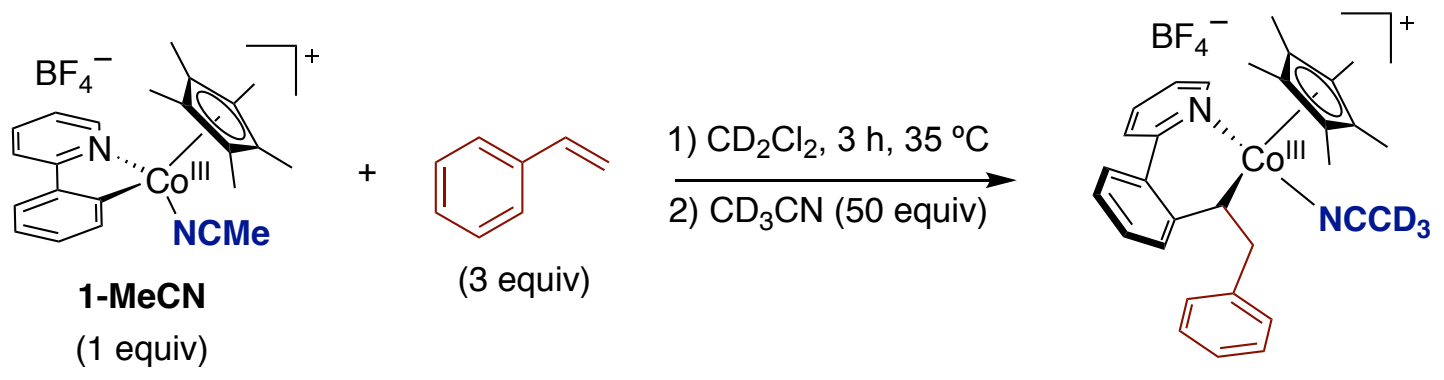

\section{2c-MeCN}

Inside the glovebox a NMR tube was loaded with 1-MeCN (4.7 mg, $0.01 \mathrm{mmol})$. The tube was then taken out and connected to the Schlenk line via an adaptor and then the solid was dissolved in $0.5 \mathrm{~mL}$ of $\mathrm{CD}_{2} \mathrm{Cl}_{2}$. After that, styrene $(3.7 \mu \mathrm{L}, 0.03 \mathrm{mmol})$ was added. After $3 \mathrm{~h}$ at $35^{\circ} \mathrm{C}$, excess of $\mathrm{CD}_{3} \mathrm{CN}(28 \mu \mathrm{L}, 0.53 \mathrm{mmol})$ was added to stabilize this reactive intermediate, and then filtered with a PTFE syringe filter. Full characterization of this reaction mixture by NMR was done afterwards.

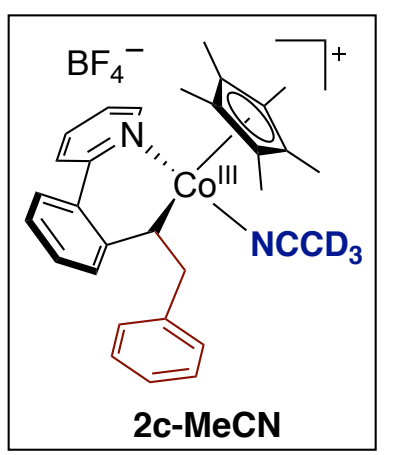

${ }^{1} \mathrm{H}$ NMR (500 MHz, $\left.\mathrm{CD}_{2} \mathrm{Cl}_{2} / \mathrm{CD}_{3} \mathrm{CN}(20: 1), 25^{\circ} \mathrm{C}\right): \delta 9.37$ (d, J = $\left.5.9 \mathrm{~Hz}, 1 \mathrm{H}\right), 7.98$ (t, J = $7.7 \mathrm{~Hz}$, $1 \mathrm{H}), 7.91(\mathrm{~d}, \mathrm{~J}=8.0 \mathrm{~Hz}, 1 \mathrm{H}), 7.56(\mathrm{t}, \mathrm{J}=6.7 \mathrm{~Hz}, 1 \mathrm{H}), 7.51(\mathrm{~d}, \mathrm{~J}=7.7 \mathrm{~Hz}, 1 \mathrm{H}), 7.17(\mathrm{t}, \mathrm{J}=7.7 \mathrm{~Hz}$, 1H), $7.11-7.00(\mathrm{~m}, 4 \mathrm{H}), 6.98(\mathrm{t}, \mathrm{J}=8.4 \mathrm{~Hz}, 1 \mathrm{H}), 6.66(\mathrm{~d}, \mathrm{~J}=7.2 \mathrm{~Hz}, 2 \mathrm{H}) 4.73(\mathrm{dd}, \mathrm{J}=11.1,5.4$ $\mathrm{Hz}, 1 \mathrm{H}), 2.53(\mathrm{dd}, \mathrm{J}=13.7,5.4 \mathrm{~Hz}, 1 \mathrm{H}), 1.96(\mathrm{~s}, 3 \mathrm{H}), 1.15(\mathrm{t}, \mathrm{J}=12.3 \mathrm{~Hz}, 1 \mathrm{H}), 1.03(\mathrm{~s}, 15 \mathrm{H})$.

${ }^{13} \mathrm{C}$ NMR (126 MHz, $\left.\mathrm{CD}_{2} \mathrm{Cl}_{2} / \mathrm{CD}_{3} \mathrm{CN}(20: 1), 25^{\circ} \mathrm{C}\right): \delta 160.36,156.66,146.70,142.24,139.50$, $137.17,130.12,129.53,128.95,128.65,128.56,127.93,126.84,126.34,125.64,124.68,123.58$, $95.25,44.23,38.84,8.43$.

${ }^{19} \mathrm{~F}$ NMR (376 MHz, $\left.\mathrm{CD}_{2} \mathrm{Cl}_{2} / \mathrm{CD}_{3} \mathrm{CN}(20: 1), 25^{\circ} \mathrm{C}\right): \delta-151.24(\mathrm{~s})$.

HRMS-ESI (m/z): [M-MeCN] $]^{+}$calcd for $\mathrm{C}_{29} \mathrm{H}_{31} \mathrm{CoN}, 452.1789$; Found, 452.1783. 


\subsection{Isolation and characterization of $2 \mathrm{~d}$.}

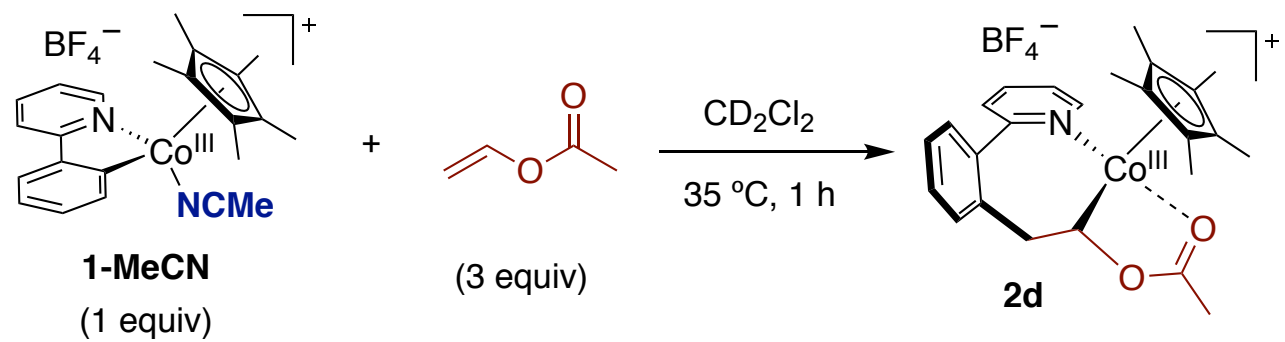

$100 \%$ isolated yield

Inside the glovebox a NMR tube was loaded with 1-MeCN (15.2 mg, $0.03 \mathrm{mmol})$. The tube was then taken out and connected to the Schlenk line via an adaptor and then the solid was dissolved in $1.5 \mathrm{~mL}$ of $\mathrm{CD}_{2} \mathrm{Cl}_{2}$. After that, vinyl acetate $(8.7 \mu \mathrm{L}, 0.09 \mathrm{mmol})$ was added. After $1 \mathrm{~h}$ at $35^{\circ} \mathrm{C}$, the reaction mixture was filtered with a PTFE syringe filter and the solvent was removed in vacuo. Further washings with $\mathrm{Et}_{2} \mathrm{O}(3 \times 5 \mathrm{~mL})$, gave rise the desired inserted cobaltacycle $\mathbf{2} \mathbf{d}$ in quantitative yield $(16.4 \mathrm{mg}, 100 \%)$ as a pure brown solid.

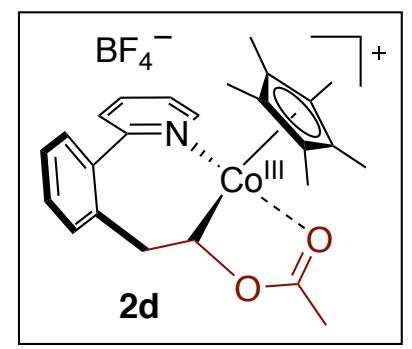

${ }^{1} \mathrm{H}$ NMR $\left(500 \mathrm{MHz}, \mathrm{CD}_{2} \mathrm{Cl}_{2}, 25^{\circ} \mathrm{C}\right): \delta 9.23(\mathrm{~d}, \mathrm{~J}=4.9 \mathrm{~Hz}, 1 \mathrm{H}), 8.07(\mathrm{td}, \mathrm{J}=7.8,1.6 \mathrm{~Hz}, 1 \mathrm{H}), 7.86$ (dd, J = 12.0, $5.3 \mathrm{~Hz}, 1 \mathrm{H}), 7.71(\mathrm{~d}, \mathrm{~J}=7.9 \mathrm{~Hz}, 1 \mathrm{H}), 7.61(\mathrm{t}, \mathrm{J}=6.0 \mathrm{~Hz}, 2 \mathrm{H}), 7.54(\mathrm{t}, \mathrm{J}=6.9 \mathrm{~Hz}$, $2 \mathrm{H}), 7.51-7.42(\mathrm{~m}, 1 \mathrm{H}), 3.23(\mathrm{dd}, \mathrm{J}=12.1,5.3 \mathrm{~Hz}, 1 \mathrm{H}), 2.23(\mathrm{~s}, 3 \mathrm{H}), 1.86(\mathrm{t}, \mathrm{J}=12.1 \mathrm{~Hz}, 1 \mathrm{H})$, $0.89(\mathrm{~s}, 15 \mathrm{H})$.

${ }^{13} \mathrm{C}$ NMR $\left(126 \mathrm{MHz}, \mathrm{CD}_{2} \mathrm{Cl}_{2}, 25^{\circ} \mathrm{C}\right) \delta 186.27,165.01,154.52,139.69,138.26,135.65,131.37$, $131.34,130.84,129.67,128.17,124.37,106.00,94.27,43.69,19.39,8.70$.

${ }^{19} \mathrm{~F}$ NMR (376 MHz, $\left.\mathrm{CD}_{2} \mathrm{Cl}_{2}, 25^{\circ} \mathrm{C}\right): \delta-151.20$ (s).

HRMS-ESI (m/z): [M] ${ }^{+}$calcd for $\mathrm{C}_{25} \mathrm{H}_{29} \mathrm{CoNO}_{2}$, 434.1530; Found, 434.1533. 


\section{Mechanistic Study on the Insertion Reaction using DPA as Model Coupling Partner}

\subsection{Influence of the $\mathrm{Cp}^{*} \mathrm{Co}{ }^{\prime \prime \prime}$ cobaltacycles}

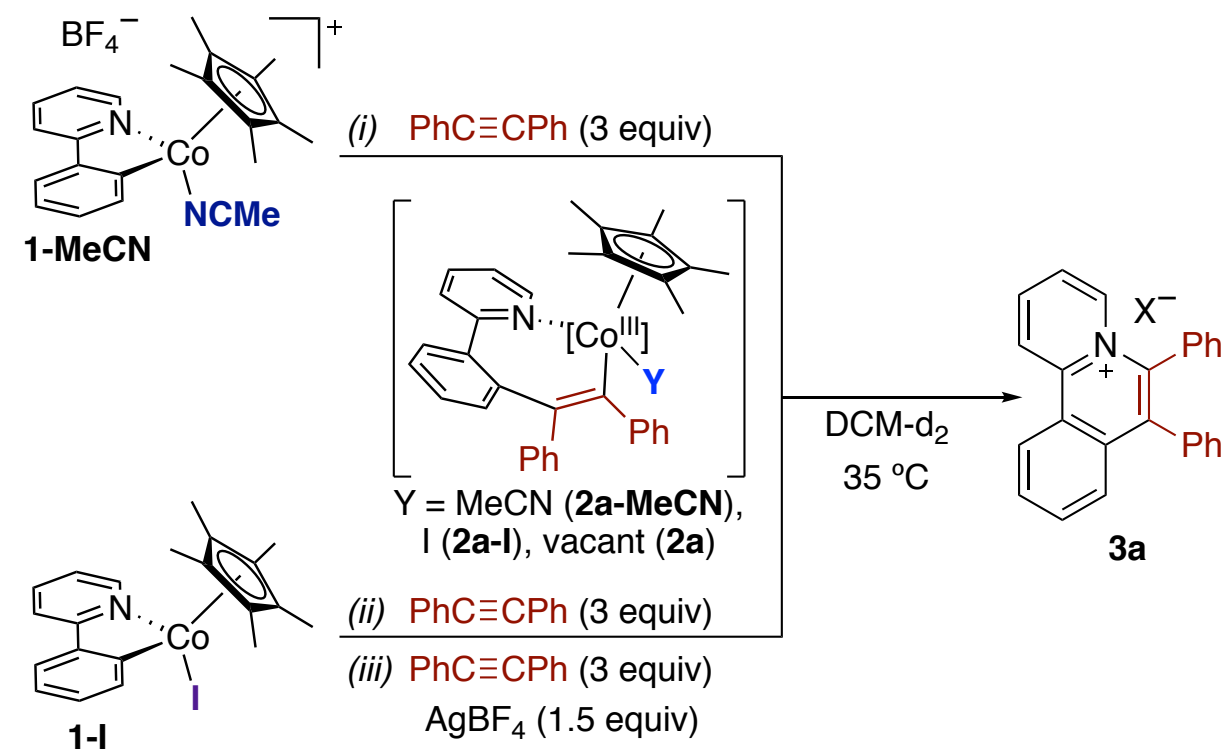

Inside the glovebox a NMR tube was loaded with 1-MeCN $(4.7 \mathrm{mg}, 0.01 \mathrm{mmol})$ or 1-I (4.8 mg, $0.01 \mathrm{mmol}$ ), diphenylacetylene (5.3 mg, $0.03 \mathrm{mmol}$ ) and $\mathrm{AgBF}_{4}(2.9 \mathrm{mg}, 0.015$ $\mathrm{mmol}$ ) if required. The tube was then taken out and connected to the Schlenk line via an adaptor and cooled down to $-35^{\circ} \mathrm{C}$. The solid was then dissolved in $0.5 \mathrm{~mL}$ of $\mathrm{CD}_{2} \mathrm{Cl}_{2}$. The reaction was kept at this temperature until transferred to the NMR instrument for measurement at $35^{\circ} \mathrm{C}$.

(i) $1-\mathrm{MeCN}+$ dpa (3 equiv)

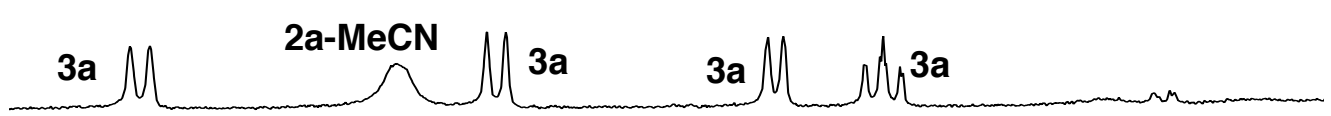

(ii) $1-I+$ dpa (3 equiv)

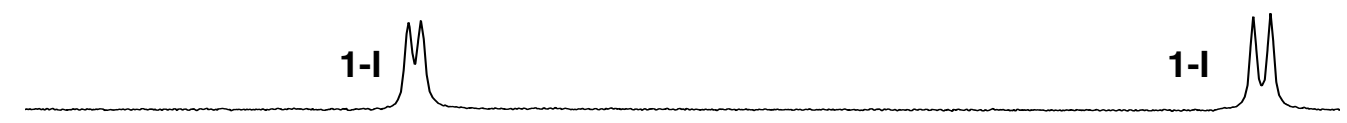

(iii) $1-\mathrm{I}+\mathrm{dpa}$ (3 equiv) $+\mathrm{AgBF}_{4}$ (1.5 equiv)

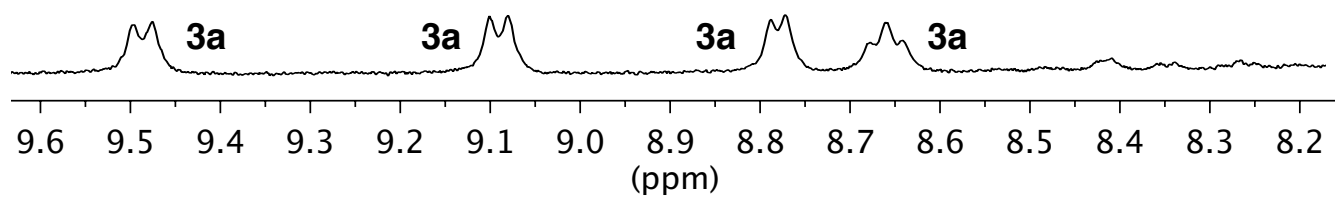

Figure S1. Sequences of ${ }^{1} \mathrm{H}$ NMR spectras corresponding to the insertion of dpa to different cobaltacycles, after $25 \mathrm{~min}$ at $35^{\circ} \mathrm{C}$. 


\section{2. $\mathrm{MeCN}$ effect}
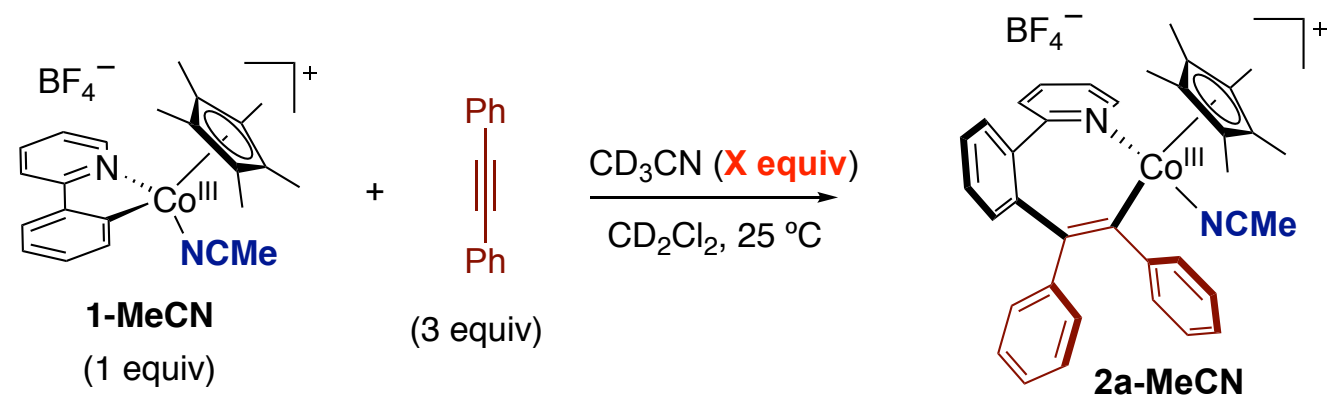

Inside the glovebox a NMR tube was loaded with 1-MeCN $(4.7 \mathrm{mg}, 0.01 \mathrm{mmol})$ and diphenylacetylene $(5.3 \mathrm{mg}, 0.03 \mathrm{mmol})$. The tube was then taken out and connected to the Schlenk line via an adaptor and cooled down to $-35^{\circ} \mathrm{C}$. The solid was then dissolved in $0.5 \mathrm{~mL}$ of $\mathrm{CD}_{2} \mathrm{Cl}_{2}$. After that, the proper amount of $\mathrm{CD}_{3} \mathrm{CN}$ was added (see table S1). The reaction was kept at this temperature until transferred to the NMR instrument for measurement at $25^{\circ} \mathrm{C}$. 1,3,5-trimetoxybencene was used as internal standard.

Table S1. Initial rates for the formation of $2 \mathrm{a}-\mathrm{MeCN}$ in $\mathrm{CD}_{2} \mathrm{Cl}_{2}$ at $25^{\circ} \mathrm{C}$, in the presence of added $\mathrm{CD}_{3} \mathrm{CN}^{\mathrm{a}}$

\begin{tabular}{ccc}
\hline $\mathrm{CD}_{3} \mathrm{CN}$ amount & {$\left[\mathrm{CD}_{3} \mathrm{CN}\right]_{\text {added }} \mathrm{mol} \mathrm{L}^{-1}$} & $\mathrm{r}_{0} / 10^{-6} \mathrm{~mol} \mathrm{~L}^{-1} \mathrm{~s}^{-1}$ \\
\hline 5 equiv $/ 2.5 \mu \mathrm{L}$ & 0.1 & 10.1 \\
10 equiv $/ 5 \mu \mathrm{L}$ & 0.2 & 4.36 \\
20 equiv $/ 10 \mu \mathrm{L}$ & 0.4 & 2.22 \\
\hline
\end{tabular}

a Up to $30 \%$ conversion
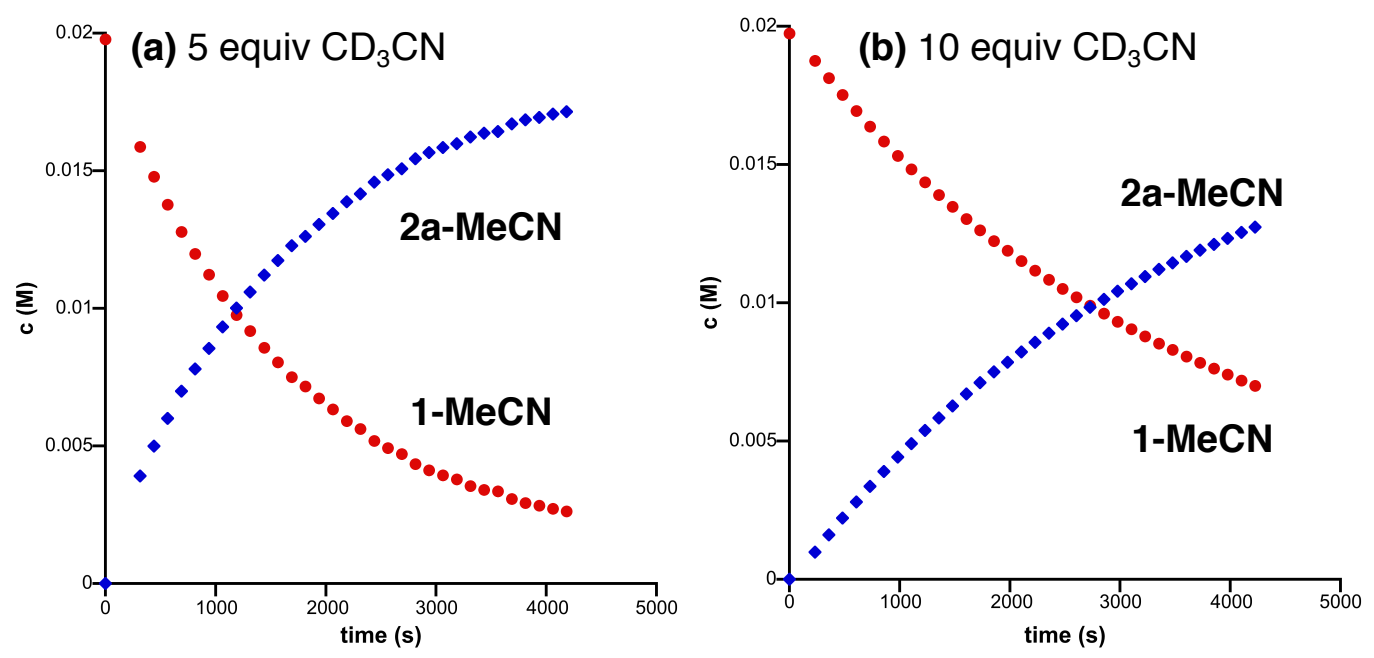


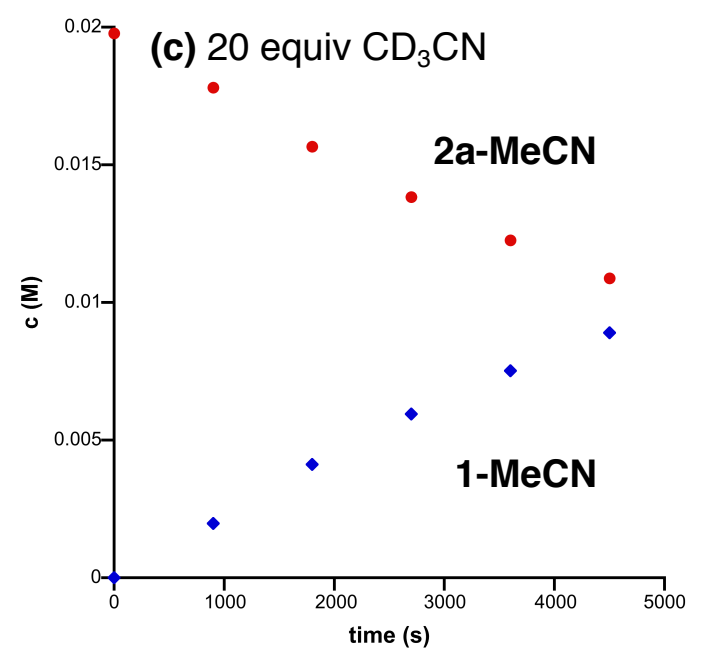

Figure S2. Concentration vs time plots for the formation of 2a-MeCN. Starting conditions [1$\mathrm{MeCN}]_{0}=0.02 \mathrm{M},[\mathrm{dpa}]_{0}=0.06 \mathrm{M}$. a) 5 equiv of MeCN. b) 10 equiv of MeCN. c) 20 equiv of $\mathrm{MeCN}$.
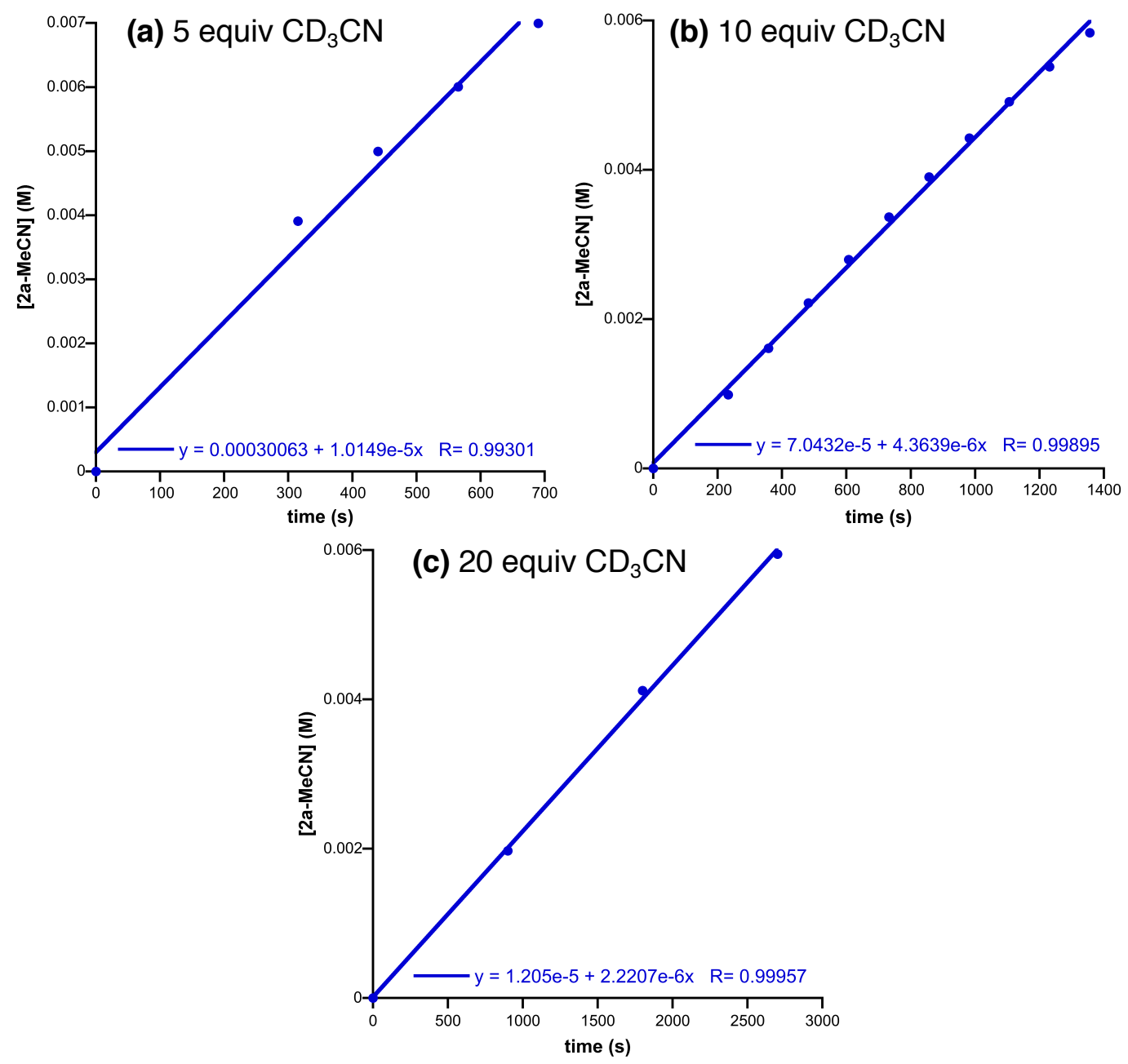

Figure S3. Obtention of the initial rates, from the slope of the $30 \%$ conversion for every reaction. a) 5 equiv of $\mathrm{MeCN}$. b) 10 equiv of MeCN. c) 20 equiv of MeCN. 


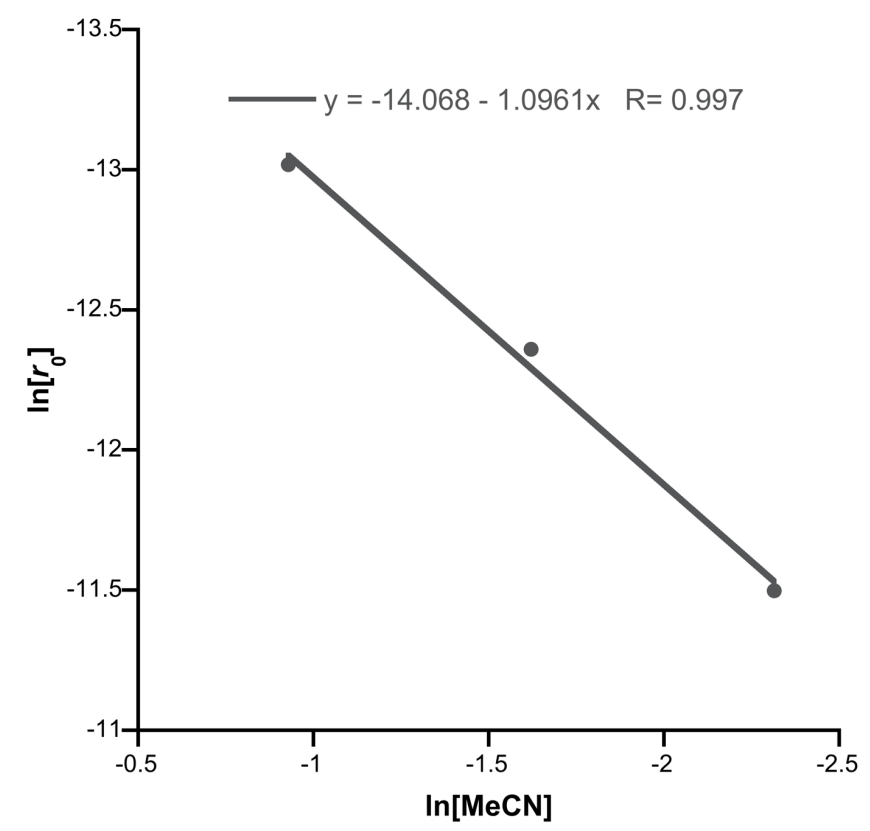

Figure S4. Plot of $\ln \left(r_{0}\right)$ vs. $\ln [\mathrm{MeCN}]$. The slope of the straight line is -1 .

\subsection{Influence of the diphenylacetylene}

\subsubsection{High temperature}
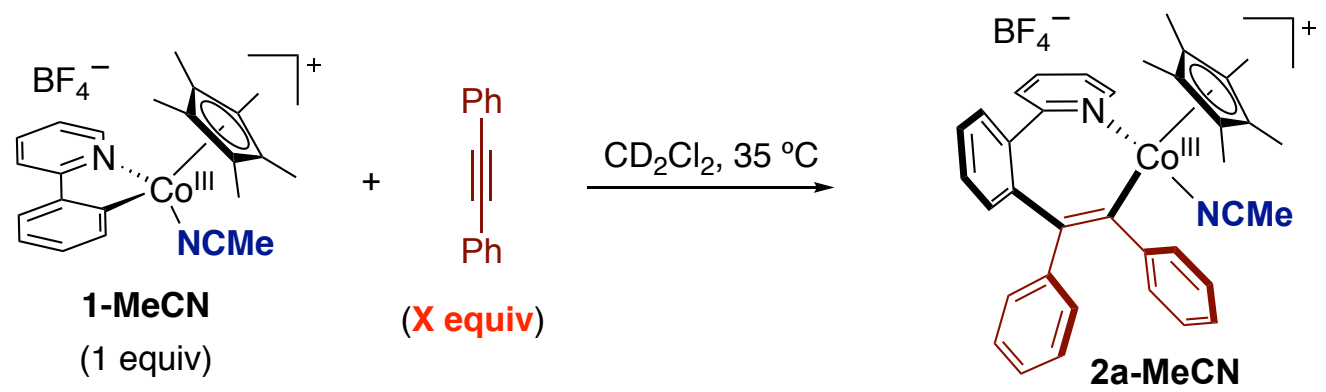

Inside the glovebox a NMR tube was loaded with 1-MeCN $(4.7 \mathrm{mg}, 0.01 \mathrm{mmol})$ and the proper amount of diphenylacetylene ( $5.3 \mathrm{mg}, 0.03 \mathrm{mmol}$ or $17.8 \mathrm{mg}, 0.1 \mathrm{mmol}$ ). The tube was then taken out and connected to the Schlenk line via an adaptor and cooled down to $-35^{\circ} \mathrm{C}$. The solid was then dissolved in $0.5 \mathrm{~mL}$ of $\mathrm{CD}_{2} \mathrm{Cl}_{2}$. The reaction was kept at this temperature until transferred to the NMR instrument for measurement at $35^{\circ} \mathrm{C}$. 1,3,5-trimetoxybencene was used as internal standard. 

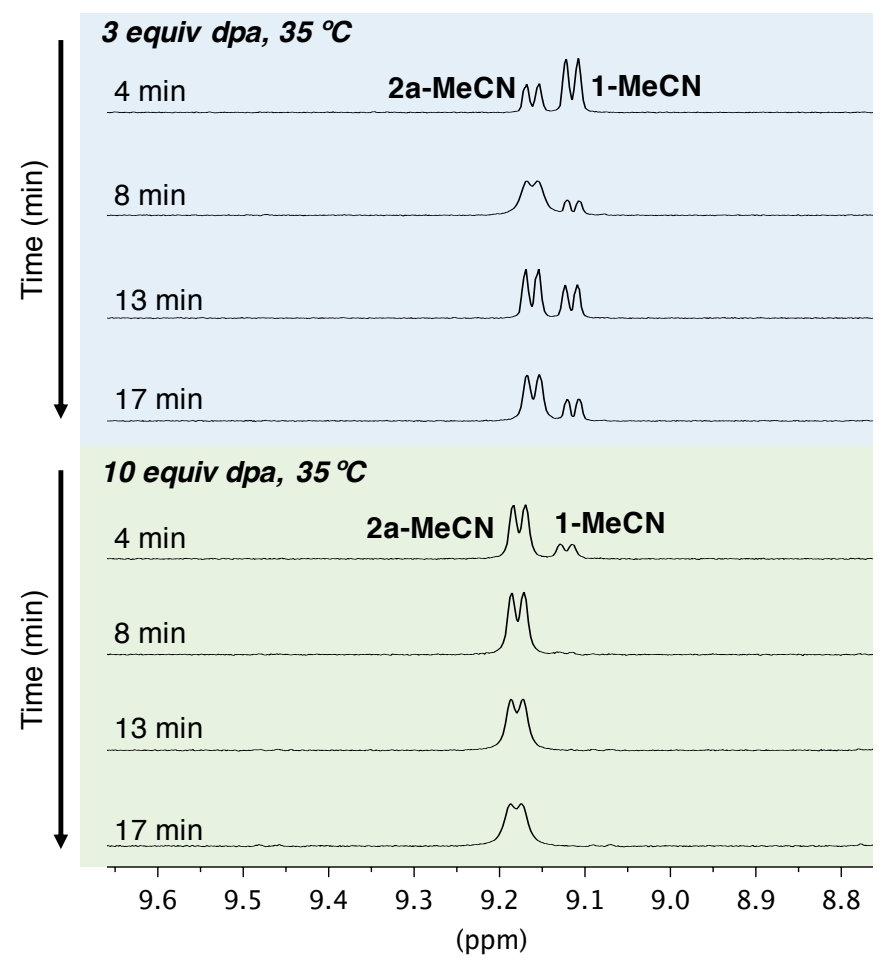

Figure S5. Sequences of ${ }^{1} \mathrm{H}$ NMR spectras corresponding to the insertion of dpa to 1-MeCN. Blue spectra are using 3 equiv of dpa. Green spectra are using 10 equiv of dpa.

\subsubsection{Low temperature}

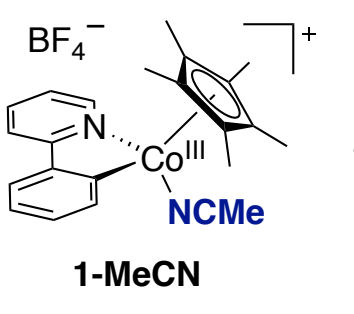

(1 equiv)<smiles>[P]C#CPc1ccccc1</smiles>

( $\mathrm{X}$ equiv)
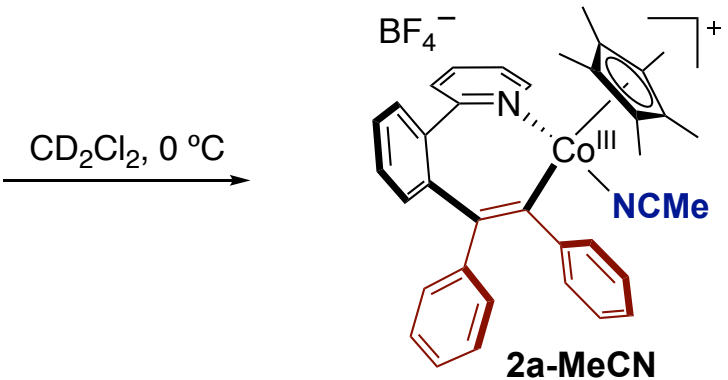

Inside the glovebox a NMR tube was loaded with 1-MeCN $(4.7 \mathrm{mg}, 0.01 \mathrm{mmol})$ and the proper amount of diphenylacetylene (see Table S2). The tube was then taken out and connected to the Schlenk line via an adaptor and cooled down to $-35^{\circ} \mathrm{C}$. The solid was then dissolved in $0.5 \mathrm{~mL}$ of $\mathrm{CD}_{2} \mathrm{Cl}_{2}$. The reaction was kept at this temperature until transferred to the NMR instrument for measurement at $0^{\circ} \mathrm{C} .1,3,5$-trimetoxybencene was used as internal standard. 
Table S2. Initial rates for the formation of $2 \mathrm{a}-\mathrm{MeCN}$ in $\mathrm{CD}_{2} \mathrm{Cl}_{2}$ at $0^{\circ} \mathrm{C}$, with varying

\begin{tabular}{ccc} 
& \multicolumn{3}{c}{ amounts of dpa. } & \\
\hline DPA equiv & [dpa] $]_{\text {added }} \mathrm{mol} \mathrm{L}^{-1}$ & $\mathrm{r}_{0} / 10^{-6} \mathrm{~mol} \mathrm{~L}^{-1} \mathrm{~s}^{-1}$ \\
\hline 3 equiv $/ 5.3 \mathrm{mg}$ & 0.06 & 2.77 \\
10 equiv / $17.8 \mathrm{mg}$ & 0.2 & 3.04 \\
\hline
\end{tabular}

a Up to $30 \%$ conversion
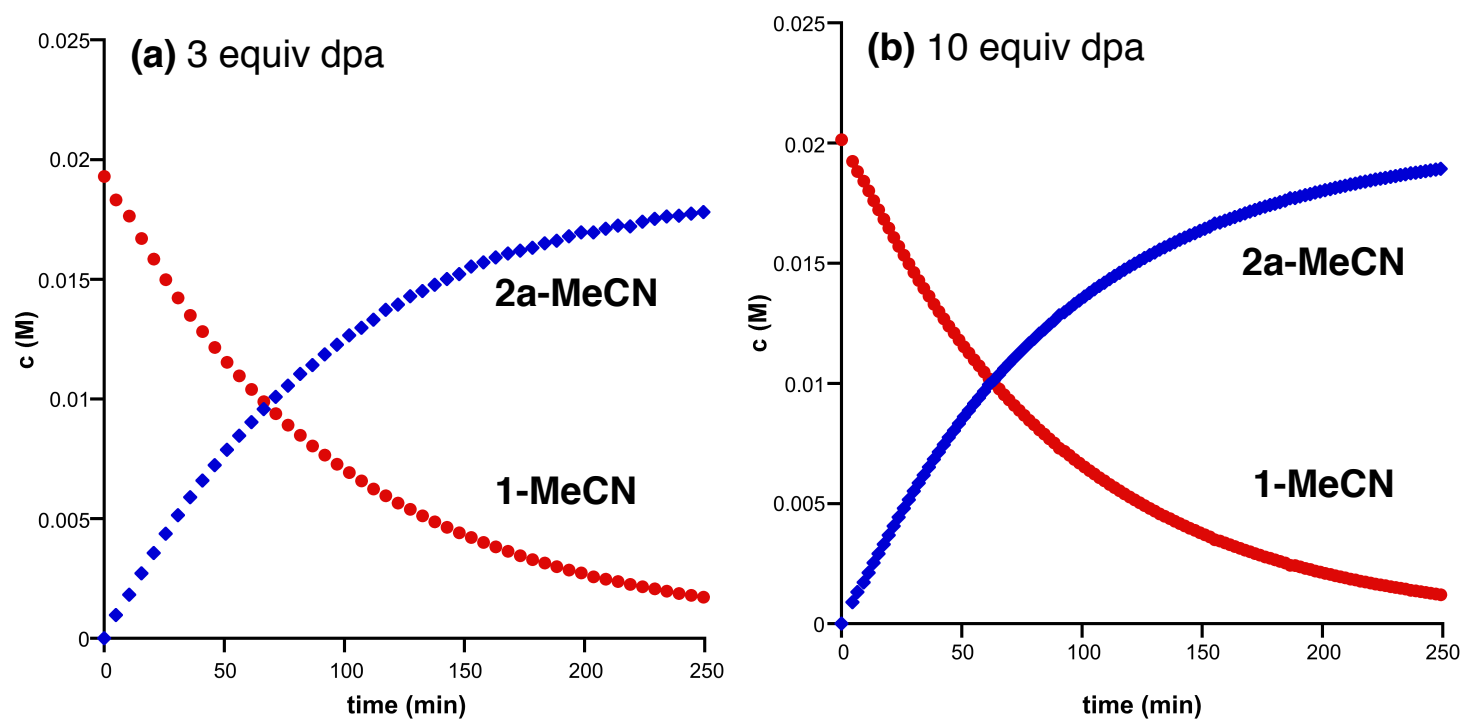

Figure S6. Concentration vs time plots for the formation of 2a-MeCN. Starting conditions [1$\mathrm{MeCN}]_{0}=0.02$ M. a) 3 equiv of dpa. b) 10 equiv of dpa.
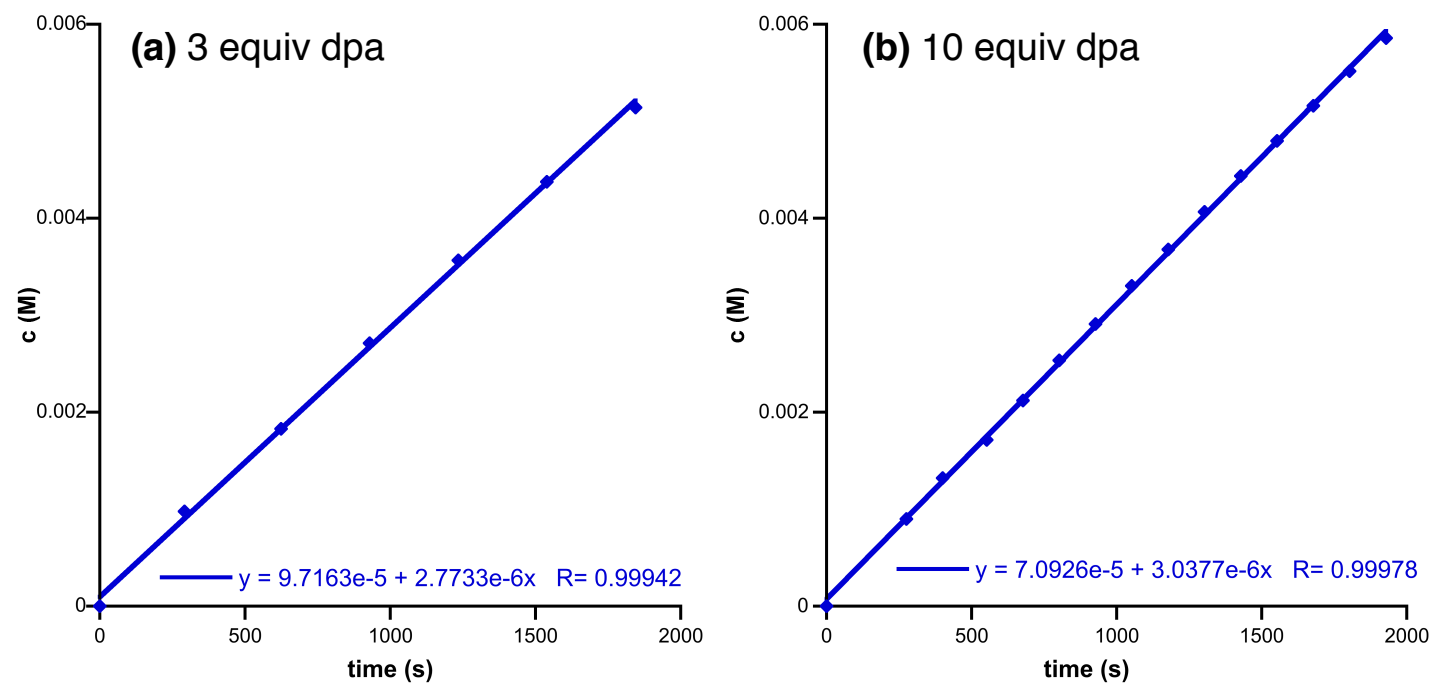

Figure S7. Obtention of the initial rates, from the slope of the $30 \%$ conversion for every reaction. a) 3 equiv of dpa. b) 10 equiv of dpa. 


\subsection{Eyring analysis for the alkyne insertion at low temperature.}
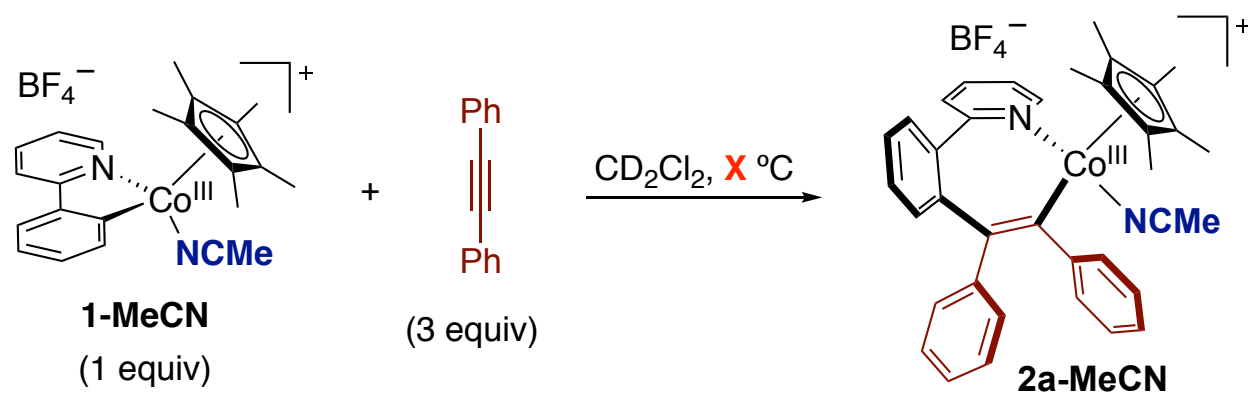

Inside the glovebox a NMR tube was loaded with 1-MeCN $(4.7 \mathrm{mg}, 0.01 \mathrm{mmol})$ and diphenylacetylene $(5.3 \mathrm{mg}, 0.03 \mathrm{mmol})$. The tube was then taken out and connected to the Schlenk line via an adaptor and cooled down to $-35^{\circ} \mathrm{C}$. The solid was then dissolved in $0.5 \mathrm{~mL}$ of $\mathrm{CD}_{2} \mathrm{Cl}_{2}$. The reaction was kept at this temperature until transferred to the NMR instrument for measurement at the temperature indicated in Table S3. 1,3,5trimetoxybencene was used as internal standard. The rate constants $\left(k_{1}\right)$ were obtained by fitting the kinetic data to the kinetic model shown in Figure S8, by nonlinear leastsquares (NLLS) regression using the program GEPASI. ${ }^{2}$
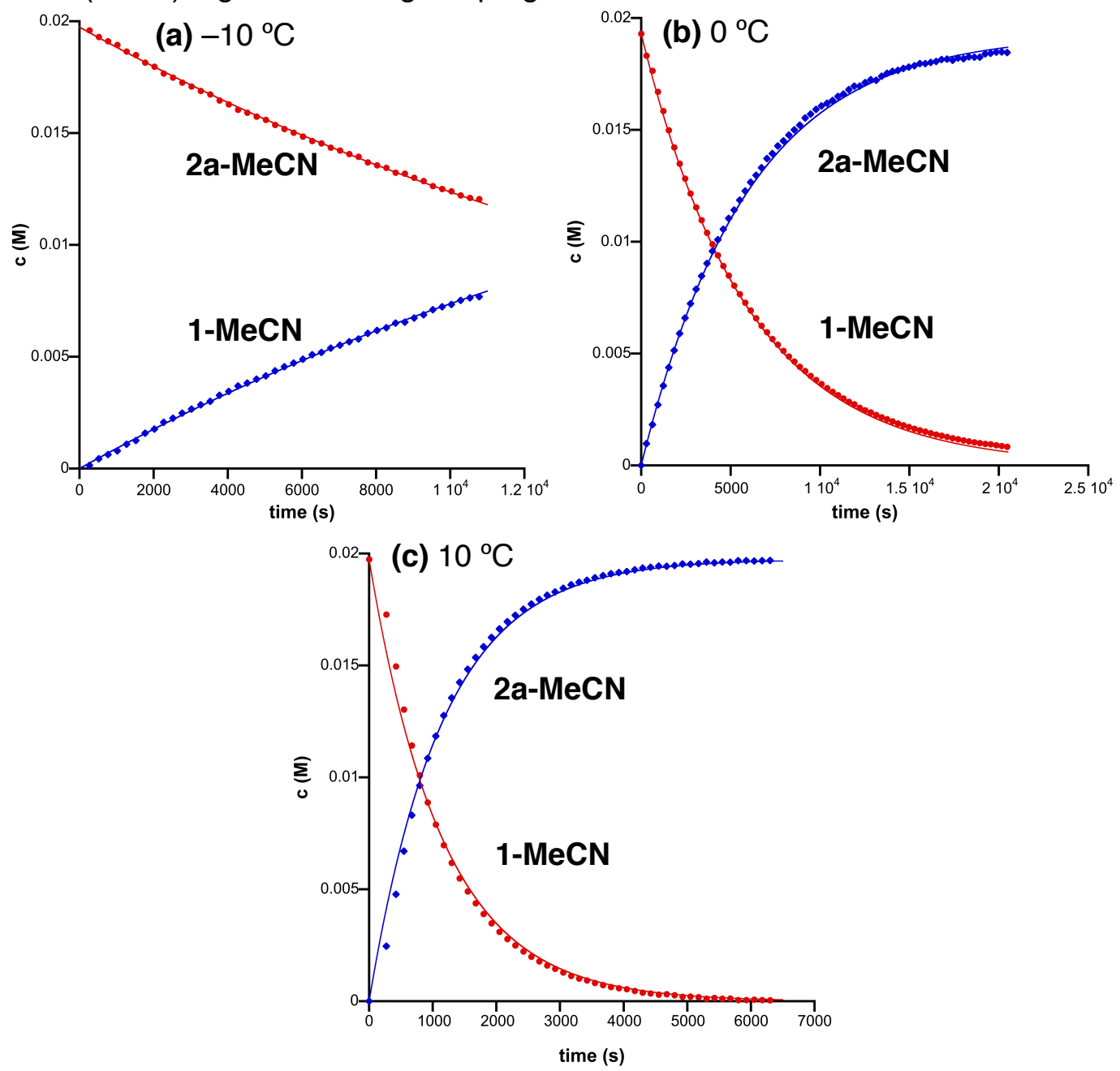

Fig S8. Concentration vs time plots for the formation of $2 a-M e C N$. Starting conditions [1$\mathrm{MeCN}]_{0}=0.02 \mathrm{M},[\mathrm{dpa}]_{0}=0.06 \mathrm{M}$. Solid lines are the best fit using Gepasi.

2 (a) Mendes, P. Bioinformatics 1993, 9, 563-571. (b) Mendes, P. Trends Biochem. Sci. 1997, 22, 361-363. (c) Mendes, P.; Kell, D. B. Bioinformatics 1998, 14, 869-883. (d) Martins, A. M.; Mendes, P.; Cordeiro, C.; Freire, A. P. Eur. J. Biochem. 2001, 268, 3930-3936. 
Table S3. Rate constants for the dpa insertion to $1-\mathrm{MeCN}$ in $\mathrm{CD}_{2} \mathrm{Cl}_{2}$ at variable

\begin{tabular}{cc} 
& temperatures. \\
\hline $\mathrm{T} / \mathrm{K}$ & $\mathrm{k}_{1} \times 10^{-5} \mathrm{~s}^{-1}$ \\
\hline 263 & 4.67 \\
273 & 16.98 \\
283 & 86.8 \\
\hline
\end{tabular}

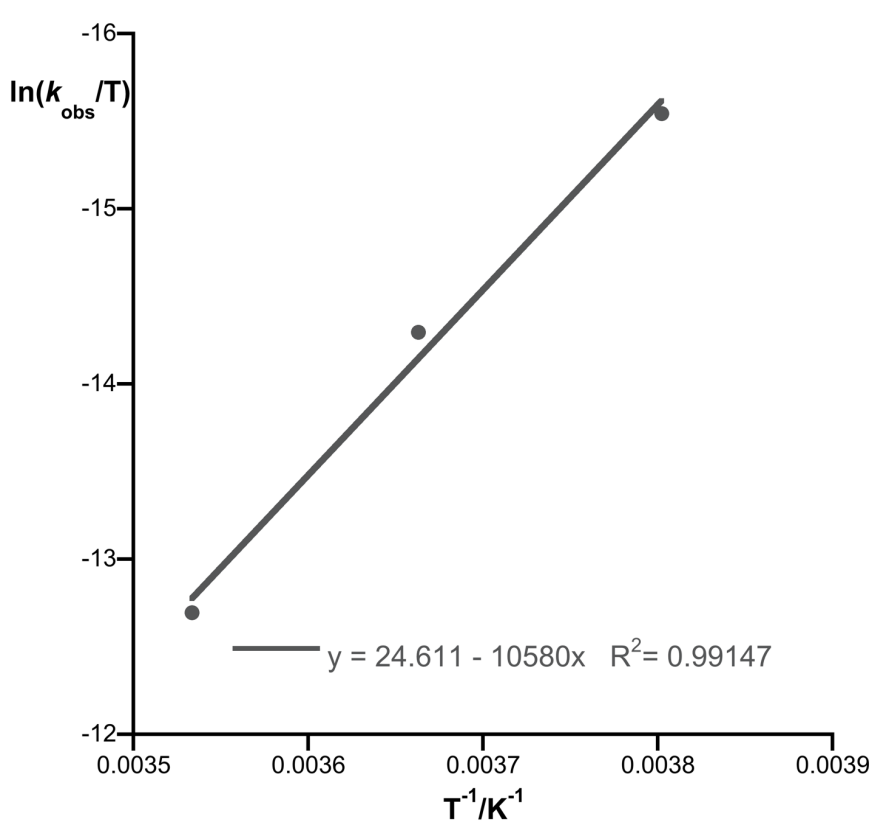

Figure S9. Eyring plot for the determination of $\Delta \mathrm{H}^{\ddagger}$ and $\Delta \mathrm{S}^{\ddagger}$ for the dpa insertion to obtain 2aMeCN.

\section{Activation parameters:}

$\Delta \mathrm{H}^{\ddagger}=21.0 \pm 1.95 \mathrm{kcal} \mathrm{mol}^{-1}$

$\Delta S^{\ddagger}=1.61 \pm 0.24 \mathrm{cal} \mathrm{K}^{-1} \mathrm{~mol}^{-1}$ 


\section{Reaction towards other unsaturated molecules}

\subsection{Terminal alkyne}

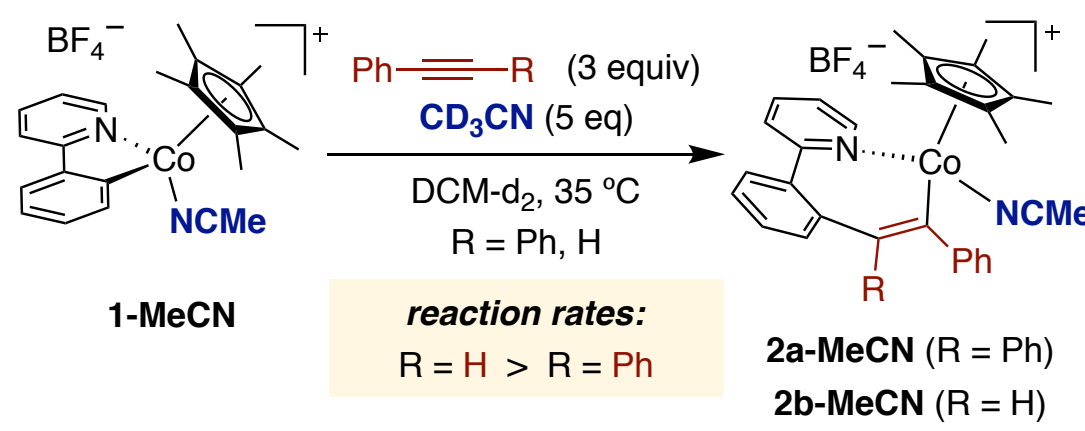

Inside the glovebox a NMR tube was loaded with 1-MeCN $(4.7 \mathrm{mg}, 0.01 \mathrm{mmol})$. The tube was then taken out and connected to the Schlenk line via an adaptor and cooled down to $-35^{\circ} \mathrm{C}$. The solid was then dissolved in $0.5 \mathrm{~mL}$ of $\mathrm{CD}_{2} \mathrm{Cl}_{2}$. After that, $\mathrm{CD}_{3} \mathrm{CN}(2.5 \mu \mathrm{L}$, $0.05 \mathrm{mmol})$ and phenylacetylene $(3.3 \mu \mathrm{L}, 0.03 \mathrm{mmol})$ were added successively. The reaction was kept at this temperature until transferred to the NMR instrument for measurement at $35^{\circ} \mathrm{C}$. In the dpa reaction, diphenylacetylene $(5.3 \mathrm{mg}, 0.03 \mathrm{mmol})$ was weighted in the glovebox. 1,3,5-trimetoxybencene was used as internal standard.

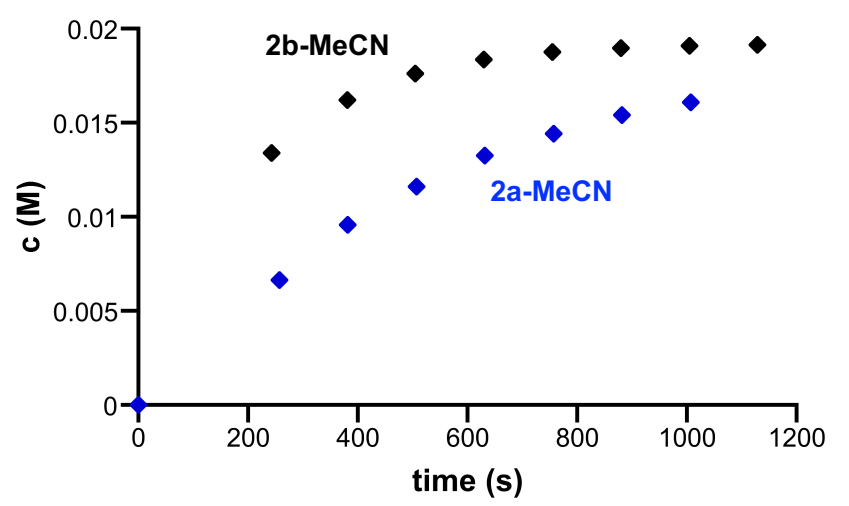

Figure S10. Concentration vs time plots comparison for the formation of $2 \mathrm{a}-\mathrm{MeCN}$ and $\mathbf{2 b}$ $\mathrm{MeCN}$. 


\subsection{Styrene}

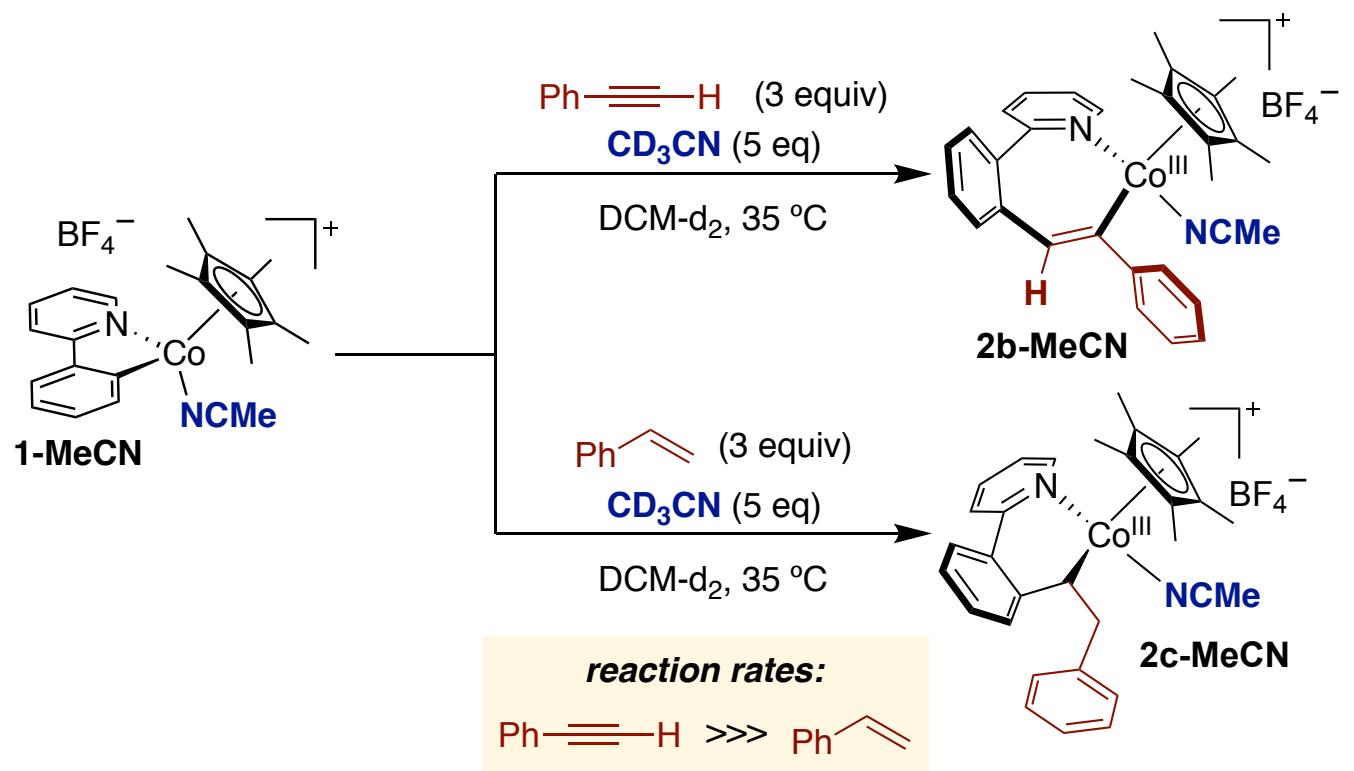

Inside the glovebox a NMR tube was loaded with 1-MeCN (4.7 mg, $0.01 \mathrm{mmol})$. The tube was then taken out and connected to the Schlenk line via an adaptor and cooled down to $-35^{\circ} \mathrm{C}$. The solid was then dissolved in $0.5 \mathrm{~mL}$ of $\mathrm{CD}_{2} \mathrm{Cl}_{2}$. After that, $\mathrm{CD}_{3} \mathrm{CN}(2.5 \mu \mathrm{L}$, $0.05 \mathrm{mmol})$ and styrene $(3.7 \mu \mathrm{L}, 0.03 \mathrm{mmol})$ were added successively. The reaction was kept at this temperature until transferred to the NMR instrument for measurement at 35 ${ }^{\circ} \mathrm{C}$. 1,3,5-trimetoxybencene was used as internal standard.

This reaction was compared with the reaction prepared in the section 5.1 with phenylacetylene.

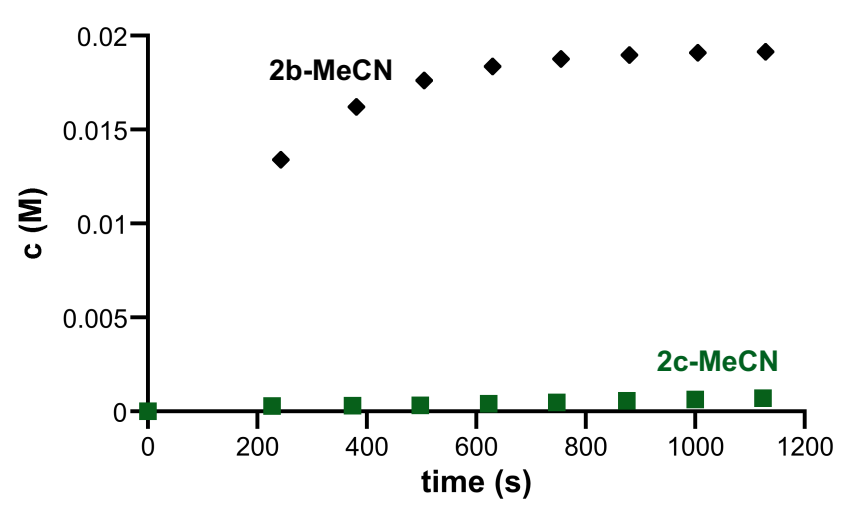

Figure S11. Concentration vs time plots comparison for the formation of $\mathbf{2 b - M e C N}$ and $\mathbf{2 c -}$ MeCN. 


\subsection{Vinyl acetate}

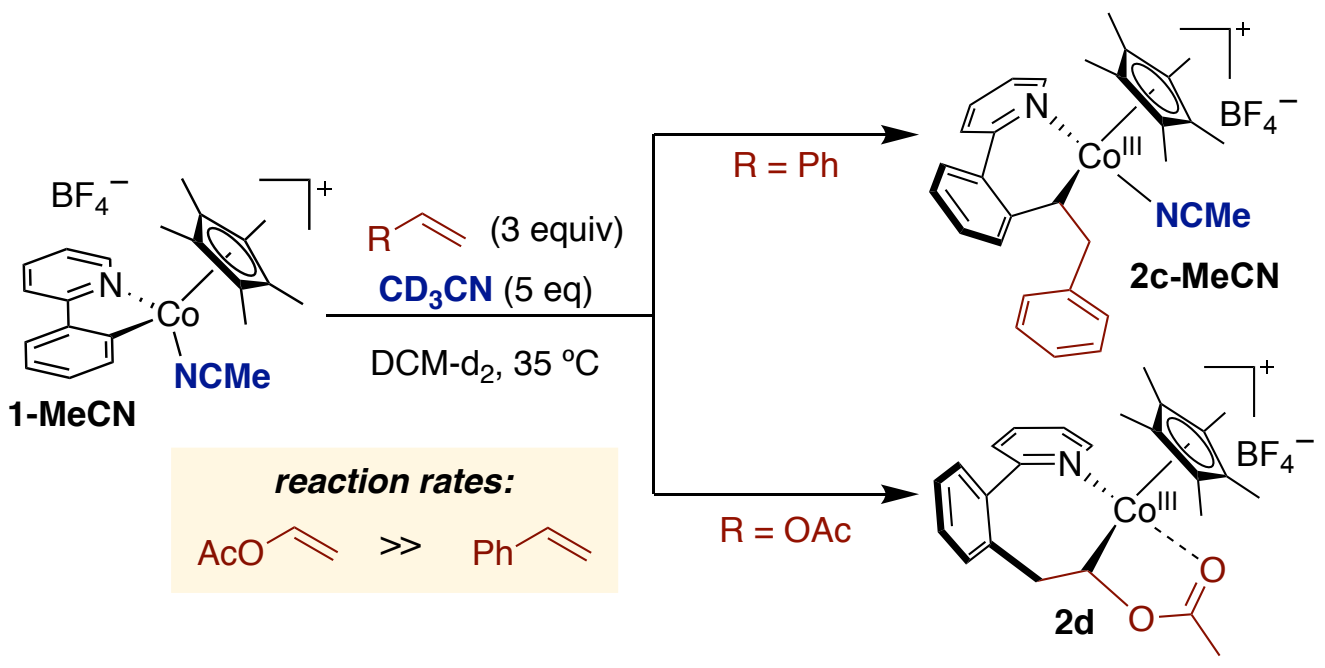

Inside the glovebox a NMR tube was loaded with 1-MeCN (4.7 mg, $0.01 \mathrm{mmol})$. The tube was then taken out and connected to the Schlenk line via an adaptor and cooled down to $-35^{\circ} \mathrm{C}$. The solid was then dissolved in $0.5 \mathrm{~mL}$ of $\mathrm{CD}_{2} \mathrm{Cl}_{2}$. After that, $\mathrm{CD}_{3} \mathrm{CN}(2.5 \mu \mathrm{L}$, $0.05 \mathrm{mmol})$ and vinyl acetate $(2.8 \mu \mathrm{L}, 0.03 \mathrm{mmol})$ were added successively. The reaction was kept at this temperature until transferred to the NMR instrument for measurement at $35^{\circ} \mathrm{C}$. 1,3,5-trimetoxybencene was used as internal standard.

This reaction was compared with the reaction prepared in the section 5.2 with styrene.

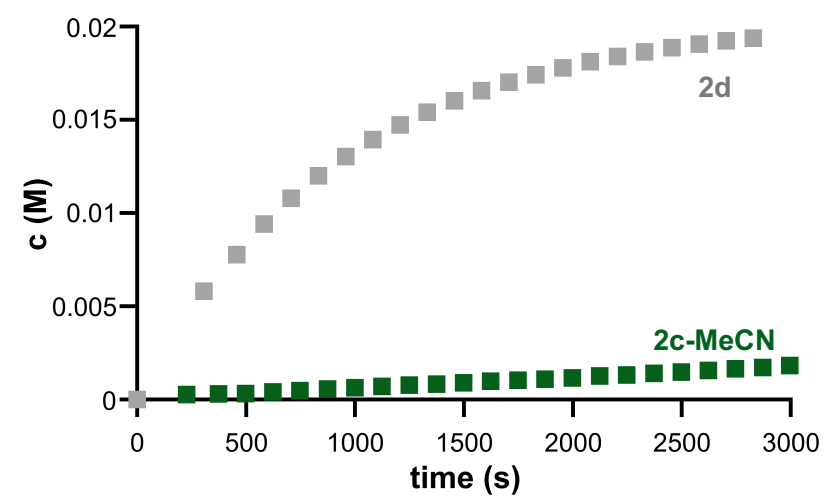

Figure S12. Concentration vs time plots comparison for the formation of $\mathbf{2 c - M e C N}$ and $\mathbf{2 d}$. 


\subsection{Ethyl vinyl ether}

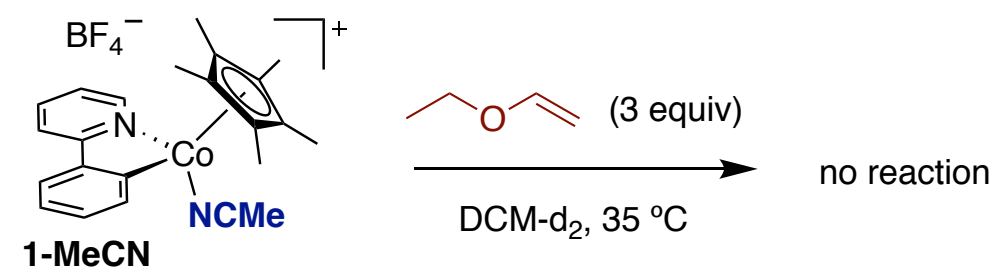

Inside the glovebox a NMR tube was loaded with 1-MeCN (4.7 mg, $0.01 \mathrm{mmol})$. The tube was then taken out and connected to the Schlenk line via an adaptor and was dissolved in $0.5 \mathrm{~mL}$ of $\mathrm{CD}_{2} \mathrm{Cl}_{2}$. After that, ethyl vinyl ether $(2.9 \mu \mathrm{L}, 0.03 \mathrm{mmol})$ was added. The reaction mixture was transferred to the NMR instrument for measurement at $35{ }^{\circ} \mathrm{C}$ inmediately. 1,3,5-trimetoxybencene was used as internal standard.

After 2 hours at this temperature, no reaction was observed (see Figure S13).
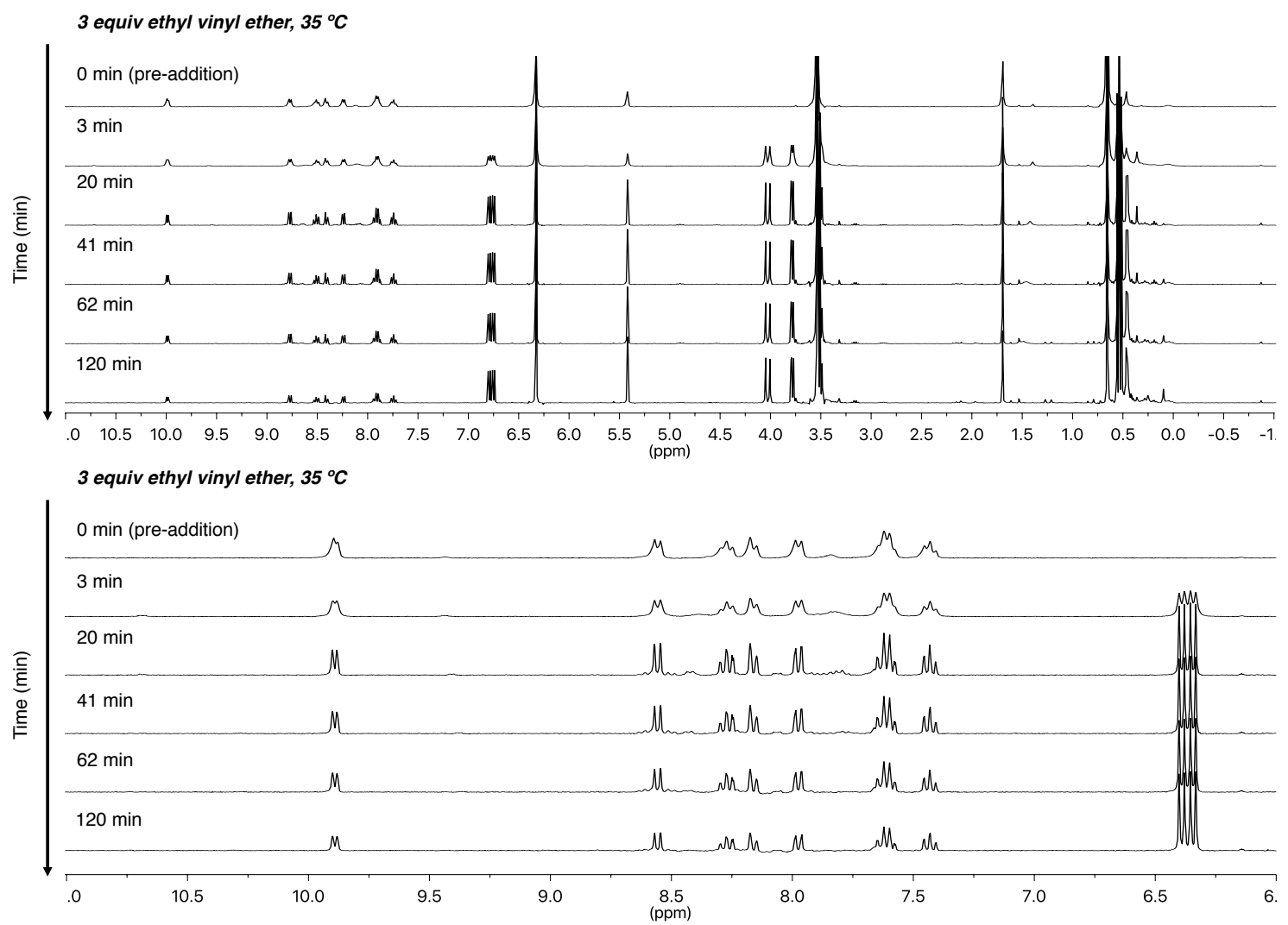

Figure S13. Stacked plot of the reaction of 1-MeCN and ethyl vinyl ether. 


\section{Single Crystal X-Ray Structure Determinations}

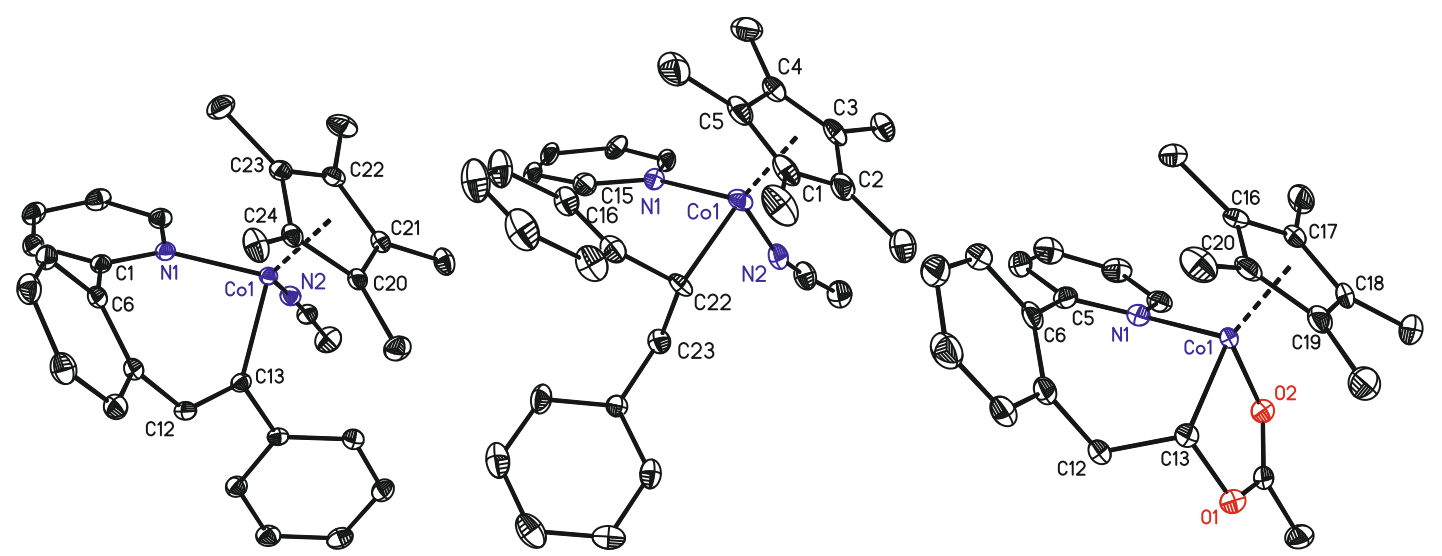

Figure S14. ORTEP drawing (thermal ellipsoids $50 \%$ ) of $\mathbf{2 b - M e C N}, \mathbf{2 c}-\mathbf{M e C N}$ and $\mathbf{2 d}$.

Crystal preparation: Crystals of $\mathbf{2 b}-\mathrm{MeCN}, \mathbf{2 c}-\mathbf{M e C N}$ and $2 \mathrm{~d}$ were grown at $-32^{\circ} \mathrm{C}$ by liquid/liquid diffusion of $n$-hexane into a solution of the corresponding complex in $\mathrm{CD}_{2} \mathrm{Cl}_{2}$. The measured crystals were prepared under inert conditions immersed in perfluoropolyether as protecting oil for manipulation.

Data collection: Crystal structure determination for $\mathbf{2 b - M e C N}$ was carried out using a Apex DUO Kappa 4-axis goniometer equipped with an APPEX $24 \mathrm{~K}$ CCD area detector, a Microfocus Source E025 luS using MoK $_{\alpha}$ radiation (0.71073 $\AA$ ), Quazar MX multilayer Optics as monochromator and a Oxford Cryosystems low temperature device Cryostream 700 plus $\left(T=-173^{\circ} \mathrm{C}\right)$. Full-sphere data collection was used with $\omega$ and $\varphi$ scans. Programs used: Data collection APEX-2 ${ }^{3}$, data reduction Bruker Saint ${ }^{4}$ V/.60A and absorption correction SADABS ${ }^{5}$.

Crystal structure determination for compounds $\mathbf{2 c - M e C N}$ and $\mathbf{2 d}$ were carried out using a Rigaku diffractometer equipped with a Pilatus $200 \mathrm{~K}$ area detector, a Rigaku MicroMax$007 \mathrm{HF}$ microfocus rotating anode with MoK $\alpha$ radiation, Confocal Max Flux optics and an Oxford Cryosystems low temperature device Cryostream 700 plus $\left(T=-173^{\circ} \mathrm{C}\right)$. Fullsphere data collection was used with $\omega$ and $\varphi$ scans. Programs used: Data collection and reduction with CrysAlisPro ${ }^{6}$ V/.60A and absorption correction with Scale3 Abspack scaling algorithm. ${ }^{7}$

Structure Solution and Refinement: Crystal structure solution was achieved using the computer program SHELXT' ${ }^{8}$. Visualization was performed with the program SHELXIe ${ }^{9}$. Missing atoms were subsequently located from difference Fourier synthesis and added to the atom list. Least-squares refinement on $\mathrm{F}^{2}$ using all measured intensities was carried out using the program SHELXL $2015^{10}$. All non-hydrogen atoms were refined including anisotropic displacement parameters.

\footnotetext{
${ }^{3}$ Data collection with APEX II v2014.9-0. Bruker (2014). Bruker AXS Inc., Madison, Wisconsin, USA.

${ }^{4}$ Data reduction with Bruker SAINT+ version V8.35A. Bruker (2013). Bruker AXS Inc., Madison, Wisconsin, USA.

${ }^{5}$ SADABS: V2014/5 Bruker (2001). Bruker AXS Inc., Madison, Wisconsin, USA. Blessing, Acta Cryst. (1995) A51 33-38.

${ }^{6}$ Data collection and reduction with CrysAlisPro 1.171.39.12b (Rigaku OD, 2015).

${ }^{7}$ Empirical absorption corrrection using spherical harmonics implemented in Scale3 Abspack scaling algorithm, CrysAlisPro 1.171.39.12b (Rigaku OD, 2015).

8 SHELXT; Sheldrick, G.M. Acta Cryst. 2015 A71, 3-8.

9 SHELXle; C.B. Huebschle, G.M. Sheldrick \& B. Dittrich; J.Appl.Cryst. (2011) 44, 1281-1284.

10 SHELXL; Sheldrick, G.M. Acta Cryst. 2015 C71, 3-8. SHELXT.
} 
Comments to the structures: $\mathbf{2 b}-\mathrm{MeCN}$ : The asymmetric unit contains one molecule of the metal complex, one $\mathrm{BF}_{4}$ anion and two dichloromethane molecules. The main molecule is disordered in two shifted positions with a ratio of 51:49. The dichloromethane molecules are disordered in two orientations with ratios of approximately 50:50. 2c-MeCN: The asymmetric contains one cationic molecule of the metal complex, one $\mathrm{BF}_{4}$ anion and two dichloromethane molecules. Both dichloromethane molecules are disordered in two orientations with a ratio of respectively 90:10 and 85:15. 2d: The asymmetric unit contains one molecule of the metal complex and one $\mathrm{BF}_{4}$ anion. This compound crystallized as a twin following the Twin law (1 000$)\left[\begin{array}{lll}1 & 0 & 0\end{array}\right]$. A HKLF 5 file was generated using the operation TwinRotMat in Platon (A.L. Spek (2009) Acta Cryst. D65, 148-155. Platon -A Multipurpose Crystallographic Tool, Utrecht University, Utrecht, The Netherlands A.L. Spek (2011).)). The BASF value refined to 0.228.

Table S4: Crystal data for compounds $2 \mathrm{~b}-\mathrm{MeCN}, 2 \mathrm{c}-\mathrm{MeCN}$ and 2d.

\begin{tabular}{|c|c|c|c|}
\hline Compound & 2b-MeCN & $2 \mathrm{c}-\mathrm{MeCN}$ & $2 d$ \\
\hline Formula & $\mathrm{C}_{66} \mathrm{H}_{76} \mathrm{~B}_{2} \mathrm{Cl}_{8} \mathrm{Co}_{2} \mathrm{~F}_{8} \mathrm{~N}_{4}$ & $\mathrm{C}_{33} \mathrm{H}_{36} \mathrm{~B}_{1} \mathrm{Cl}_{4} \mathrm{Co}_{1} \mathrm{~F}_{4} \mathrm{~N}_{2}$ & $\mathrm{C}_{25} \mathrm{H}_{29} \mathrm{~B}_{1} \mathrm{Co}_{1} \mathrm{~F}_{4} \mathrm{~N}_{1} \mathrm{O}_{2}$ \\
\hline Solvents & $2 \times \mathrm{CH}_{2} \mathrm{Cl}_{2}$ & $2 \times \mathrm{CH}_{2} \mathrm{Cl}_{2}$ & \\
\hline Formula weight & 1500.38 & 748.18 & 1360.51 \\
\hline Crystal size $\left(\mathrm{mm}^{3}\right)$ & $0.05 \times 0.10 \times 0.15$ & $0.20 \times 0.30 \times 0.40$ & $0.30 \times 0.06 \times 0.04$ \\
\hline Crystal color & brown & yellow & red \\
\hline Chem. Formula & $\mathrm{C}_{66} \mathrm{H}_{76} \mathrm{~B}_{2} \mathrm{Cl}_{8} \mathrm{Co}_{2} \mathrm{~F}_{8} \mathrm{~N}_{4}$ & $\mathrm{C}_{33} \mathrm{H}_{36} \mathrm{~B}_{1} \mathrm{Cl}_{4} \mathrm{Co}_{1} \mathrm{~F}_{4} \mathrm{~N}_{2}$ & $\mathrm{C}_{25} \mathrm{H}_{29} \mathrm{~B}_{1} \mathrm{Co}_{1} \mathrm{~F}_{4} \mathrm{~N}_{1} \mathrm{O}_{2}$ \\
\hline Temp (K) & 100 & 100 & 100 \\
\hline Crystal system & Triclinic & Monoclinic & Monoclinic \\
\hline Space group & $P-1$ & $P 2{ }_{1} / \mathrm{c}$ & $P 21 / \mathrm{c}$ \\
\hline$A(\AA)$ & $11.1562(7)$ & $14.3896(3)$ & $8.4860(5)$ \\
\hline $\mathrm{B}(\AA)$ & $12.1685(8)$ & $16.4231(3)$ & $20.2522(12)$ \\
\hline$C(\AA)$ & $13.5568(8)$ & $14.5526(3)$ & $13.7940(8)$ \\
\hline$\alpha(\mathrm{deg})$ & $76.8852(18)$ & 90 & 90 \\
\hline$\beta$ (deg) & $89.9460(18)$ & $105.647(2)$ & $98.879(6)$ \\
\hline$\gamma(\mathrm{deg})$ & $74.3783(18)$ & 90 & 90 \\
\hline$V\left(\AA^{3}\right)$ & $1722.63(19)$ & $3311.64(13)$ & $2342.2(2)$ \\
\hline $\mathbf{z}$ & 1 & 4 & 4 \\
\hline$\rho\left(\mathrm{g} / \mathrm{cm}^{3}\right)$ & 1.446 & 1.501 & 1.478 \\
\hline$\mu\left(\mathrm{mm}^{-1}\right)$ & 0.856 & 0.891 & 0.788 \\
\hline$\theta_{\max }\left({ }^{\circ}\right)$ & 31.416 & 32.488 & 28.35 \\
\hline Reflec. measured & 17651 & 38540 & 11473 \\
\hline Unique reflections & $7390\left[\mathrm{R}_{\mathrm{int}}=0.0419\right]$ & $9261\left[R_{\text {int }}=0.0403\right]$ & $6612\left[R_{\text {int }}=0.1025\right]$ \\
\hline Absorpt. correct. & SADABS & Scale3 Abspack & Scale3 Abspack \\
\hline Trans. $\min / \max$ & $0.5812 / 0.7462$ & $0.828 / 0.985$ & $1.000 / 0.890$ \\
\hline Parameters/Restrains & $776 / 712$ & $459 / 102$ & $314 / 0$ \\
\hline $\mathrm{R} 1 / w R 2[\mathrm{I}>2 \sigma(\mathrm{I})]$ & $0.0472 / 0.1235$ & $0.0350 / 0.0888$ & $0.0568 / 0.1346$ \\
\hline R1/wR2 [all data] & $0.0647 / 0.1362$ & $0.0429 / 0.0915$ & $0.1043 / 0.1500$ \\
\hline Goodness-of-fit $\left(F^{2}\right)$ & 1.038 & 1.061 & 0.955 \\
\hline Special refinement & --- & --- & $\begin{array}{l}\text { 2-component twin; Twin Law (1 } 0 \\
0)\left[\begin{array}{lll}1 & 0 & 0\end{array}\right]\end{array}$ \\
\hline Peak/hole $\left(\mathrm{e} / \AA^{3}\right)$ & $0.729 / 0.581$ & $0.515 / \quad 0.366$ & $0.720 / \quad 0.449$ \\
\hline
\end{tabular}




\section{NMR Characterization}

\subsection{NMR Characterization of complex $2 \mathrm{~b}-\mathrm{MeCN}$}

${ }^{1} \mathrm{H}$ NMR spectra of $2 \mathrm{~b}-\mathrm{MeCN}$ at $25^{\circ} \mathrm{C}\left(\mathrm{CD}_{2} \mathrm{Cl}_{2} / \mathrm{CD}_{3} \mathrm{CN}(50: 1)\right)$

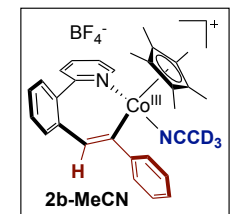

- Excess of phenylacetylene

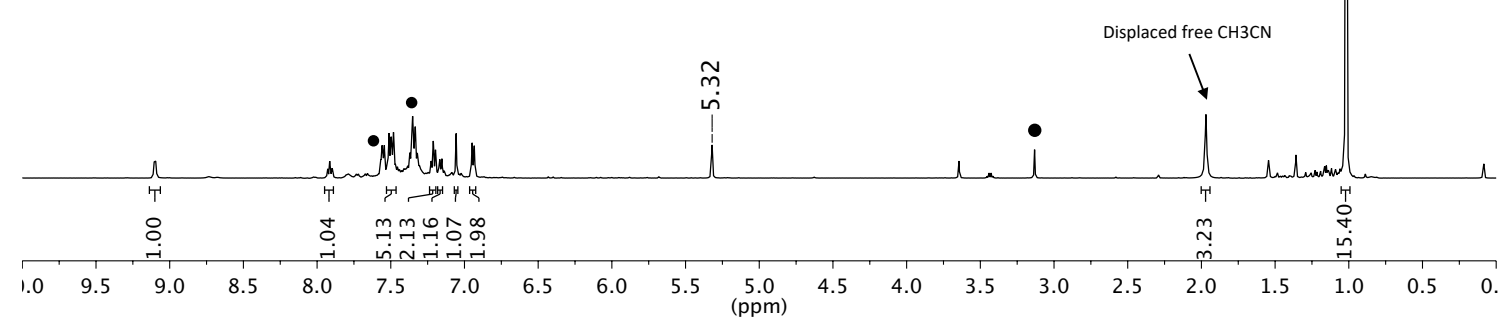

- Excess of phenylacetylene

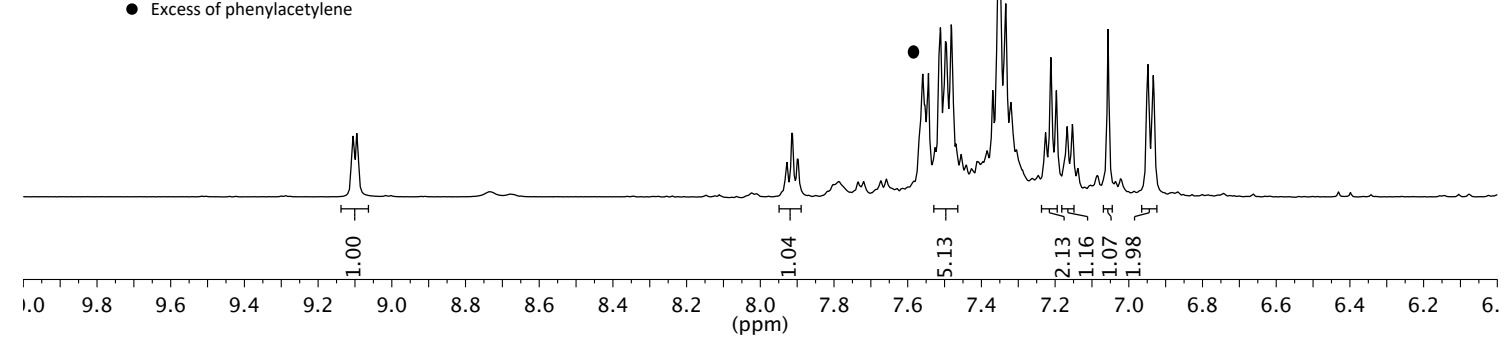


${ }^{13} \mathrm{C}$ NMR spectra of $2 \mathrm{~b}-\mathrm{MeCN}$ at $25{ }^{\circ} \mathrm{C}\left(\mathrm{CD}_{2} \mathrm{Cl}_{2} / \mathrm{CD}_{3} \mathrm{CN}(50: 1)\right)$
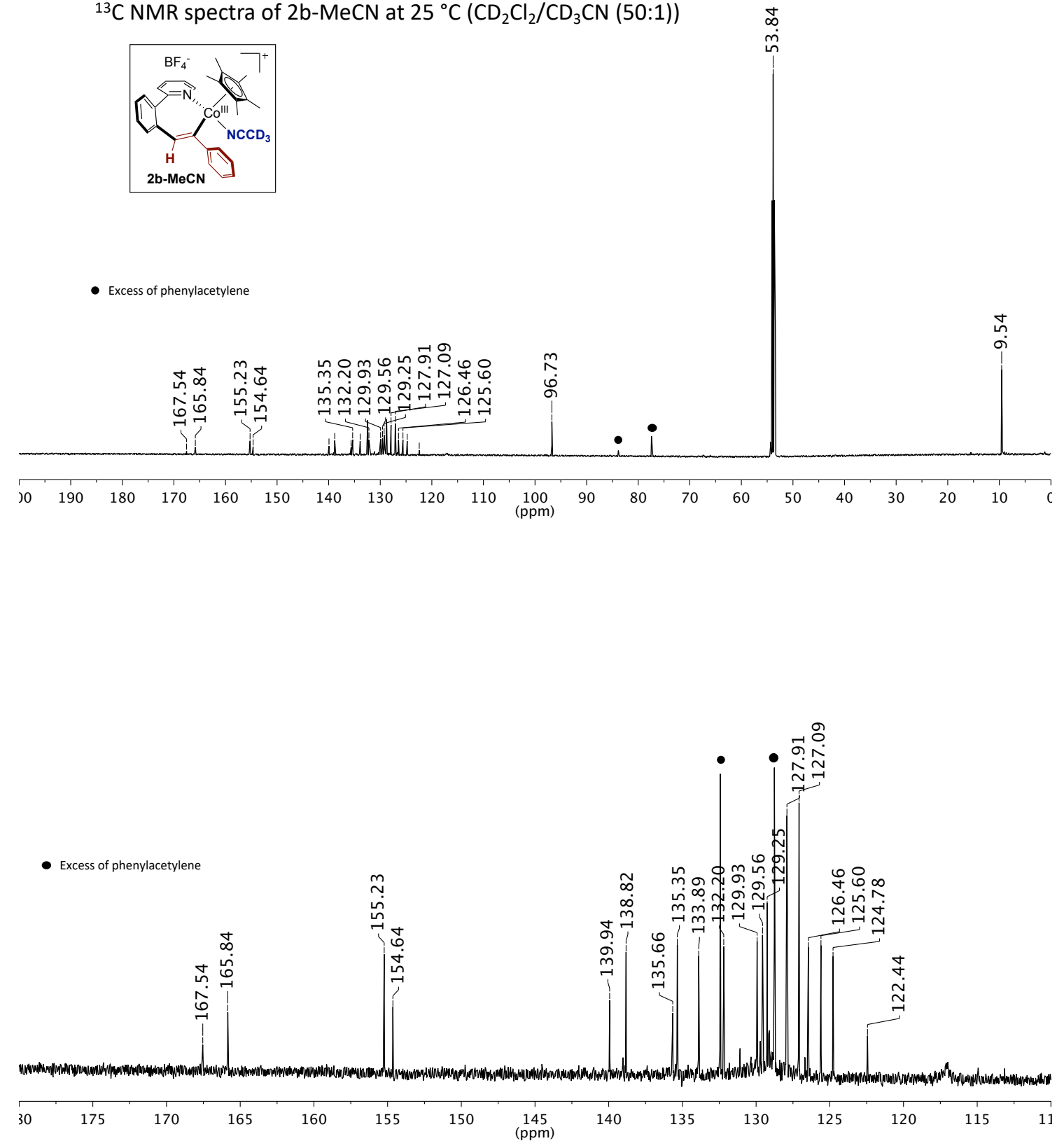

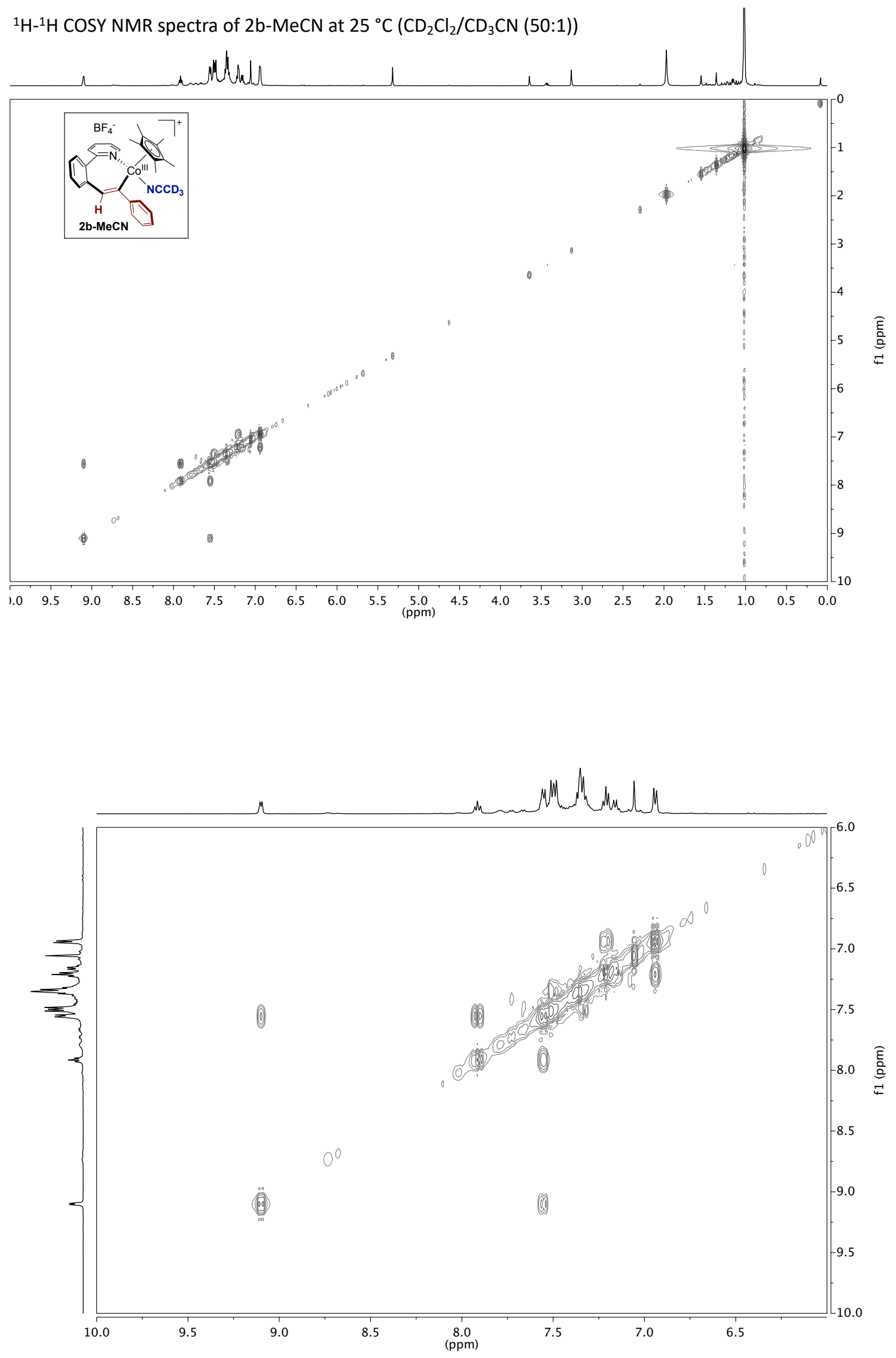

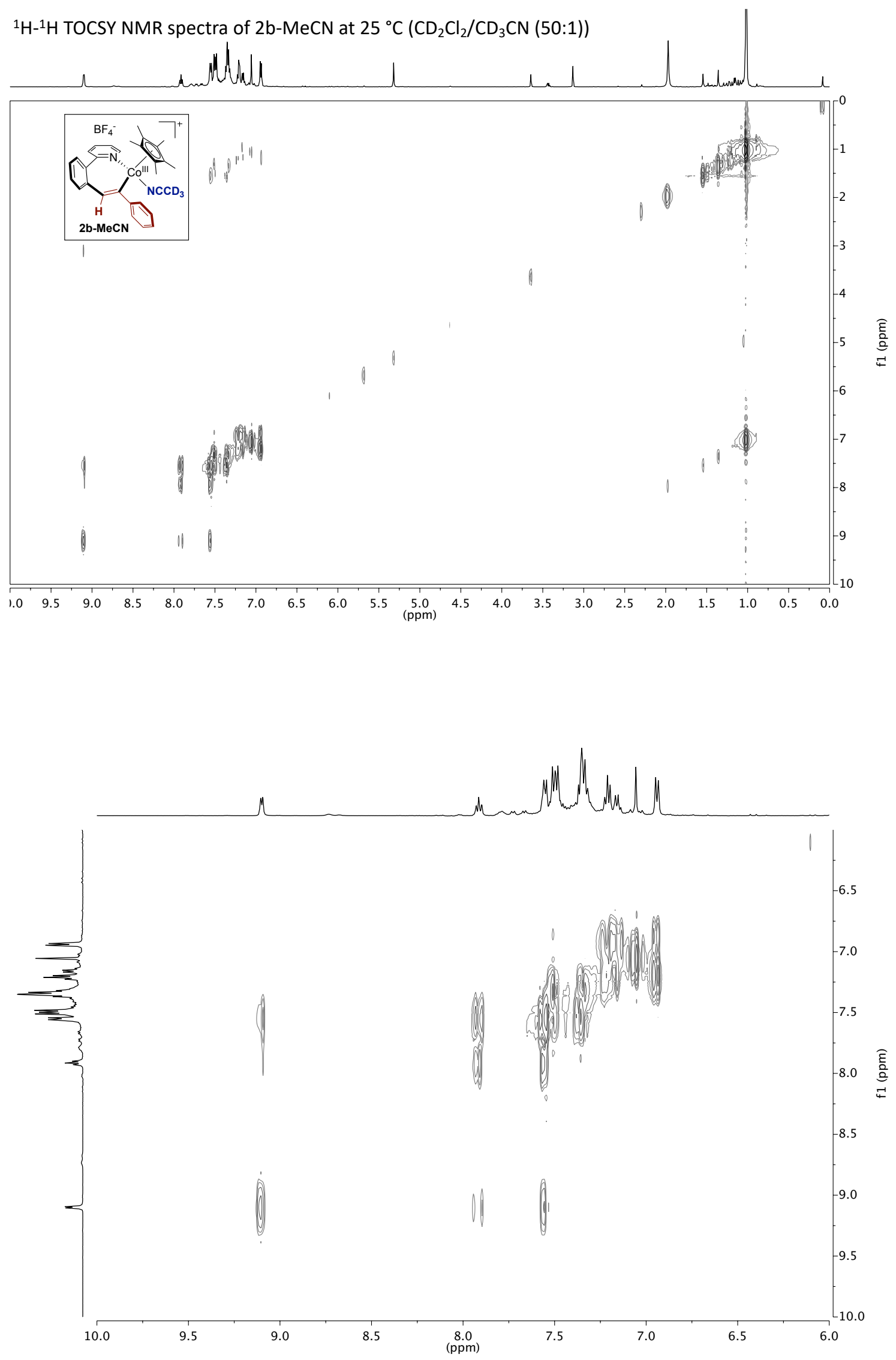

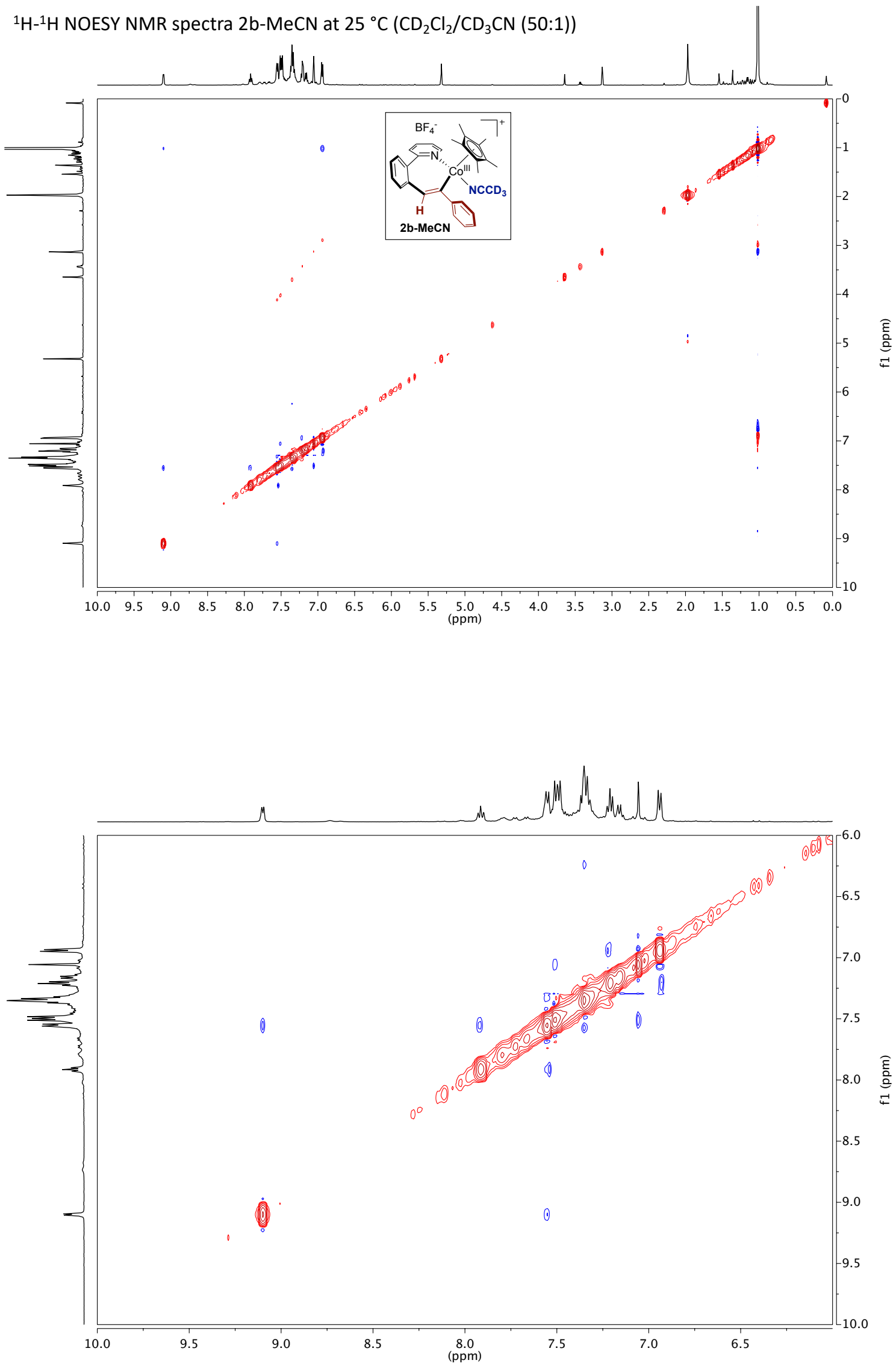

S24 

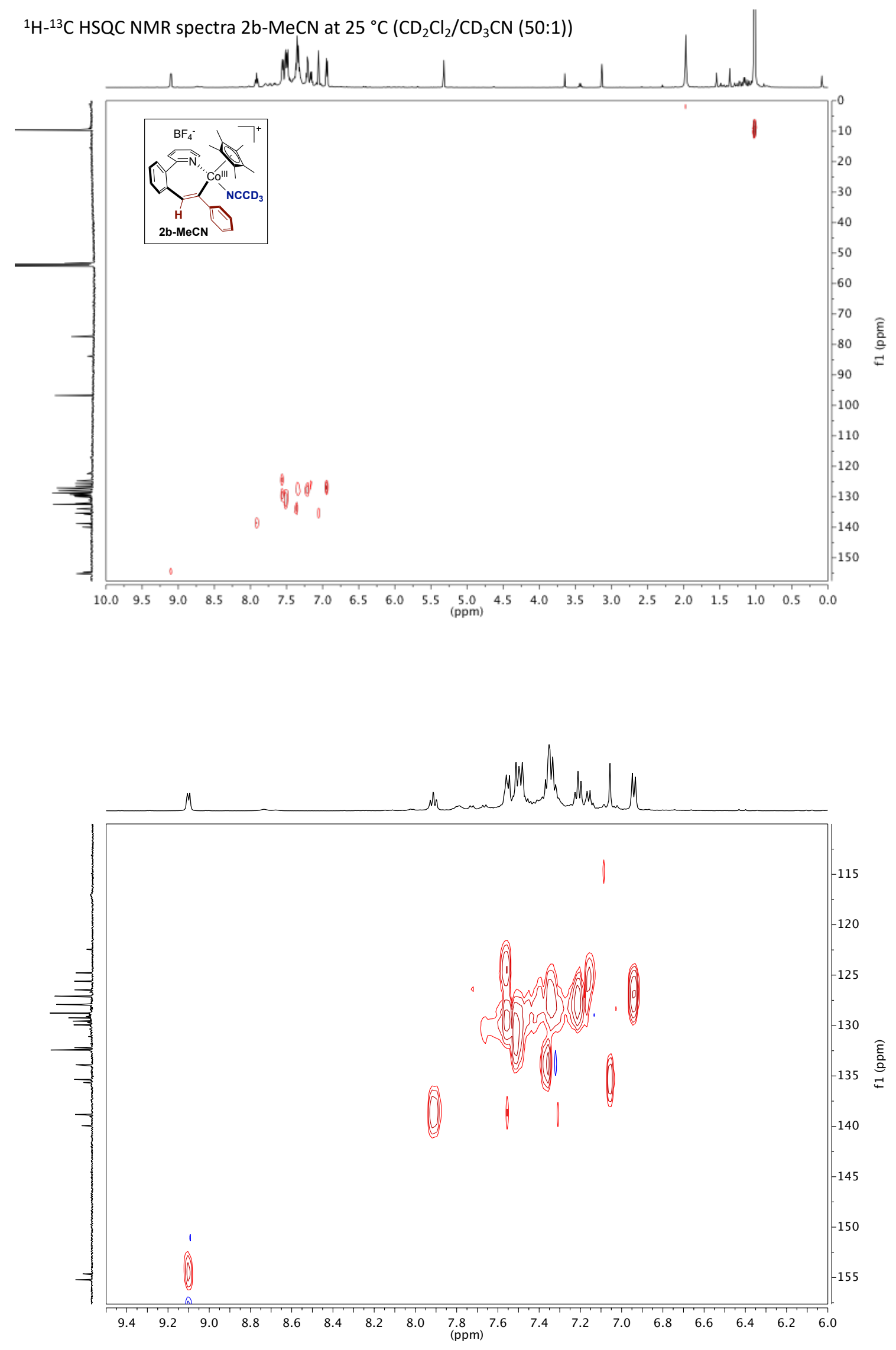

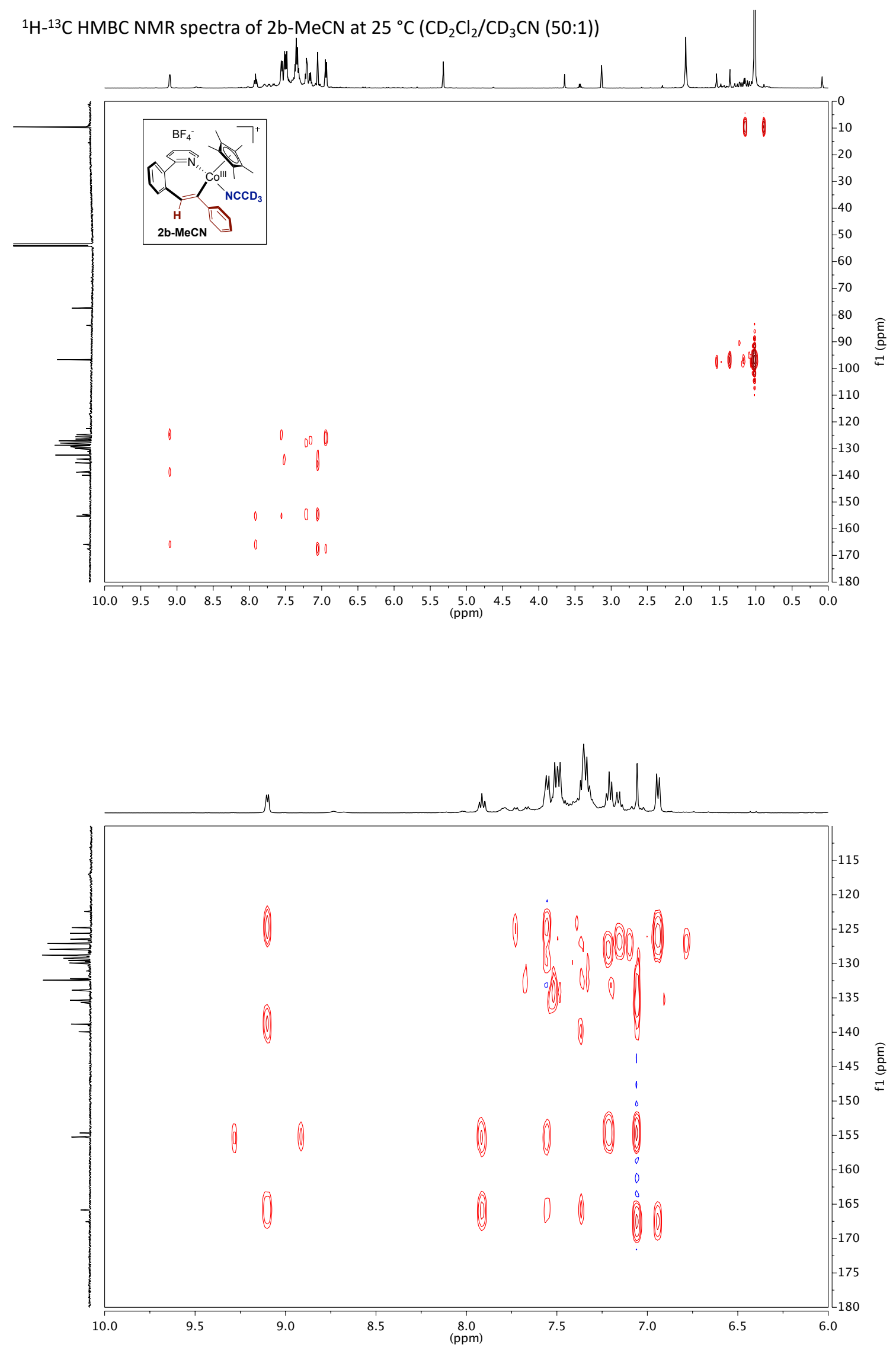
${ }^{19} \mathrm{~F}$ NMR spectra of $2 \mathrm{~b}-\mathrm{MeCN}$ at $25{ }^{\circ} \mathrm{C}\left(\mathrm{CD}_{2} \mathrm{Cl}_{2} / \mathrm{CD}_{3} \mathrm{CN}(50: 1)\right)$
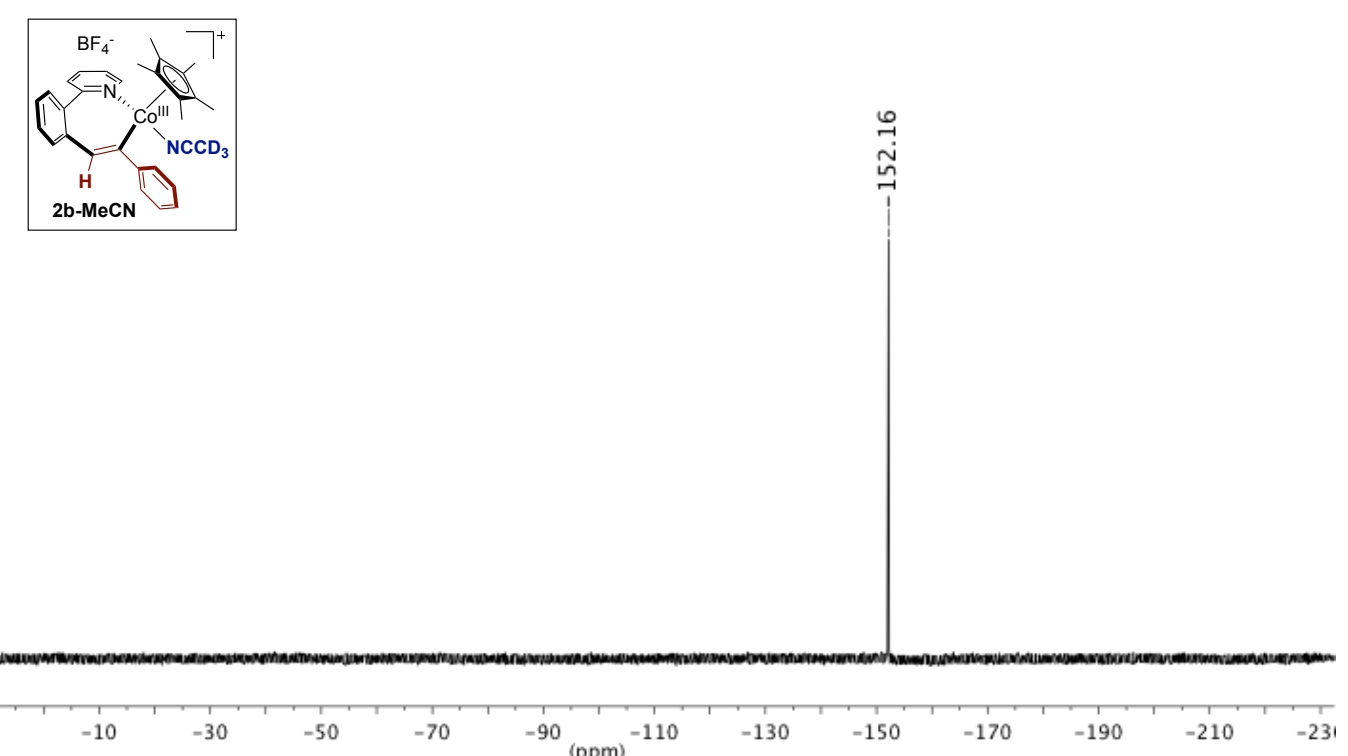


\subsection{NMR Characterization of complex 2c-MeCN}

${ }^{1} \mathrm{H}$ NMR spectra of $2 \mathrm{c}-\mathrm{MeCN}$ at $25{ }^{\circ} \mathrm{C}\left(\mathrm{CD}_{2} \mathrm{Cl}_{2} / \mathrm{CD}_{3} \mathrm{CN}(20: 1)\right)$

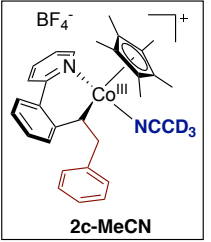

- Excess of styrene
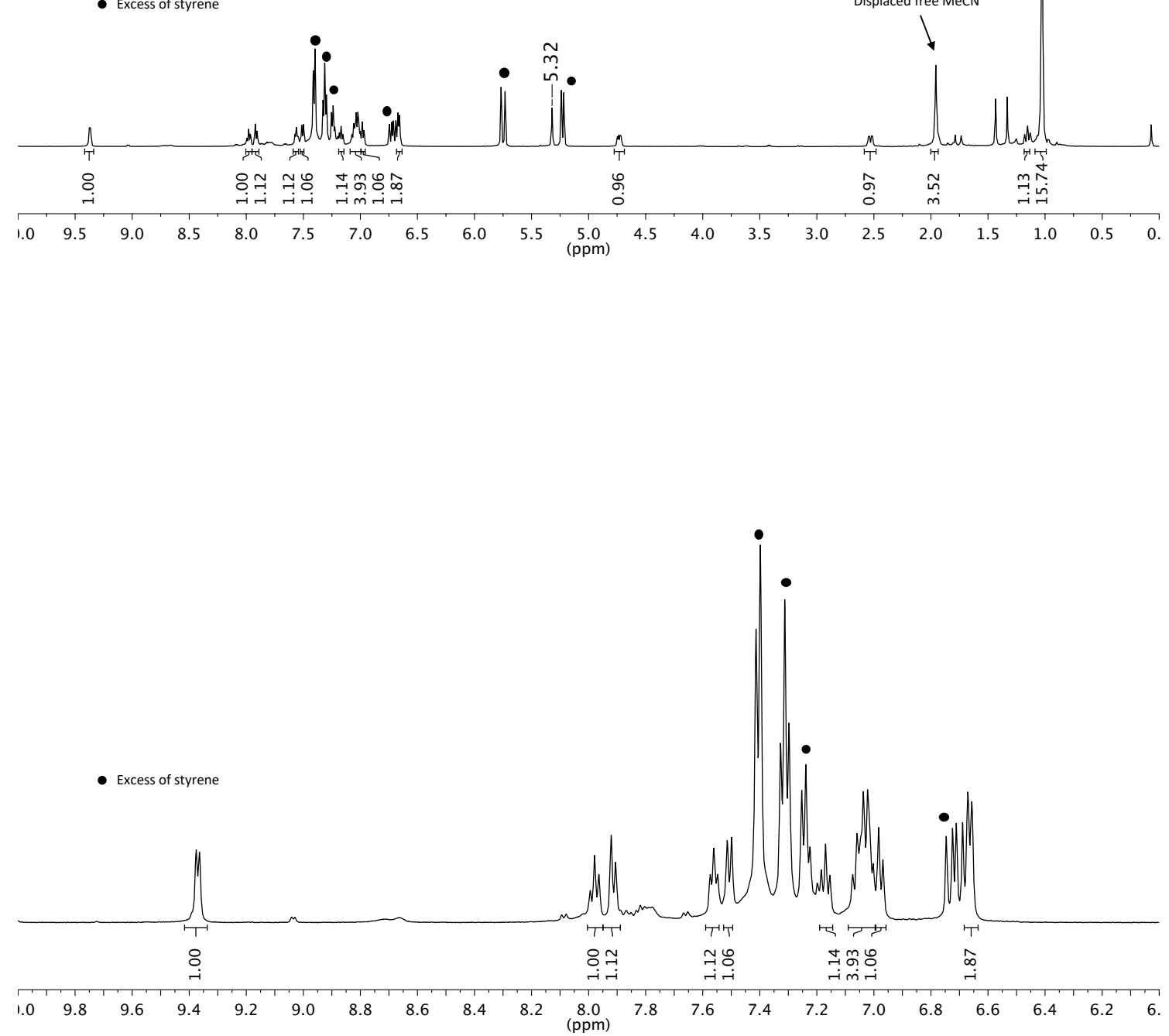
${ }^{13} \mathrm{C}$ NMR spectra of $2 \mathrm{C}-\mathrm{MeCN}$ at $25{ }^{\circ} \mathrm{C}\left(\mathrm{CD}_{2} \mathrm{Cl}_{2} / \mathrm{CD}_{3} \mathrm{CN}(20: 1)\right)$
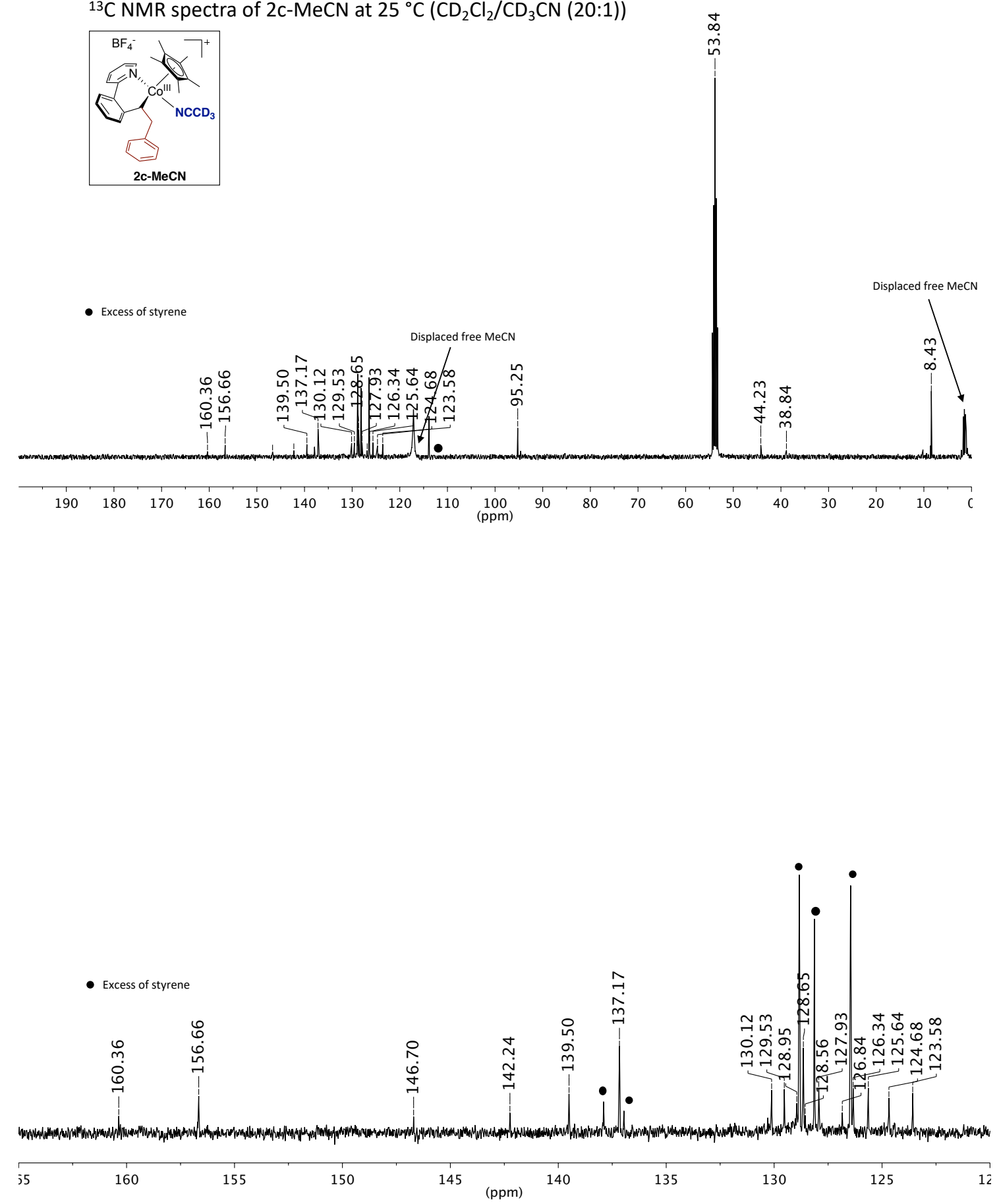

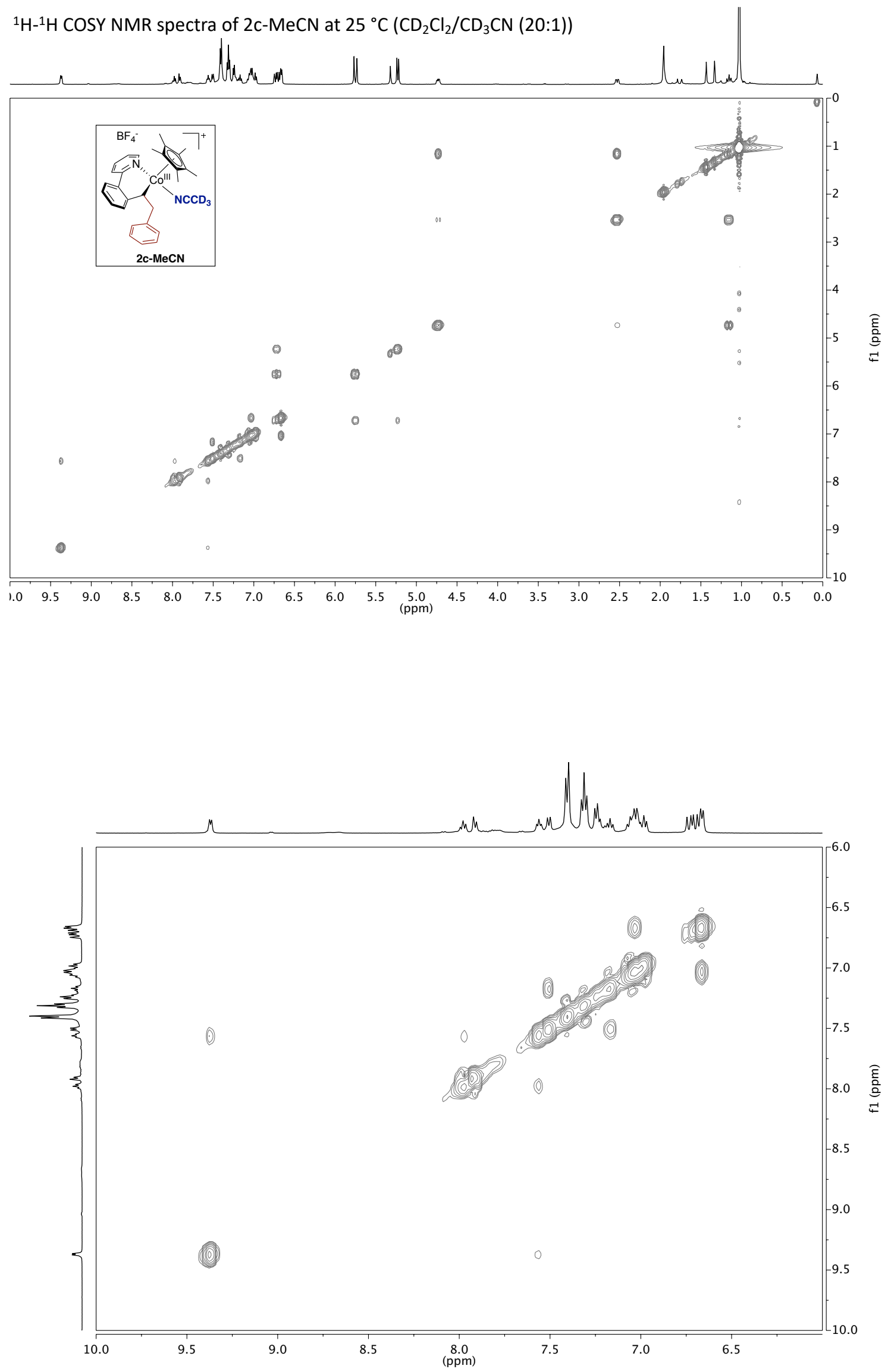
${ }^{1} \mathrm{H}-{ }^{-1} \mathrm{H}$ TOCSY NMR spectra of $2 \mathrm{c}-\mathrm{MeCN}$ at $25^{\circ} \mathrm{C}\left(\mathrm{CD}_{2} \mathrm{Cl}_{2} / \mathrm{CD}_{3} \mathrm{CN}(20: 1)\right)$
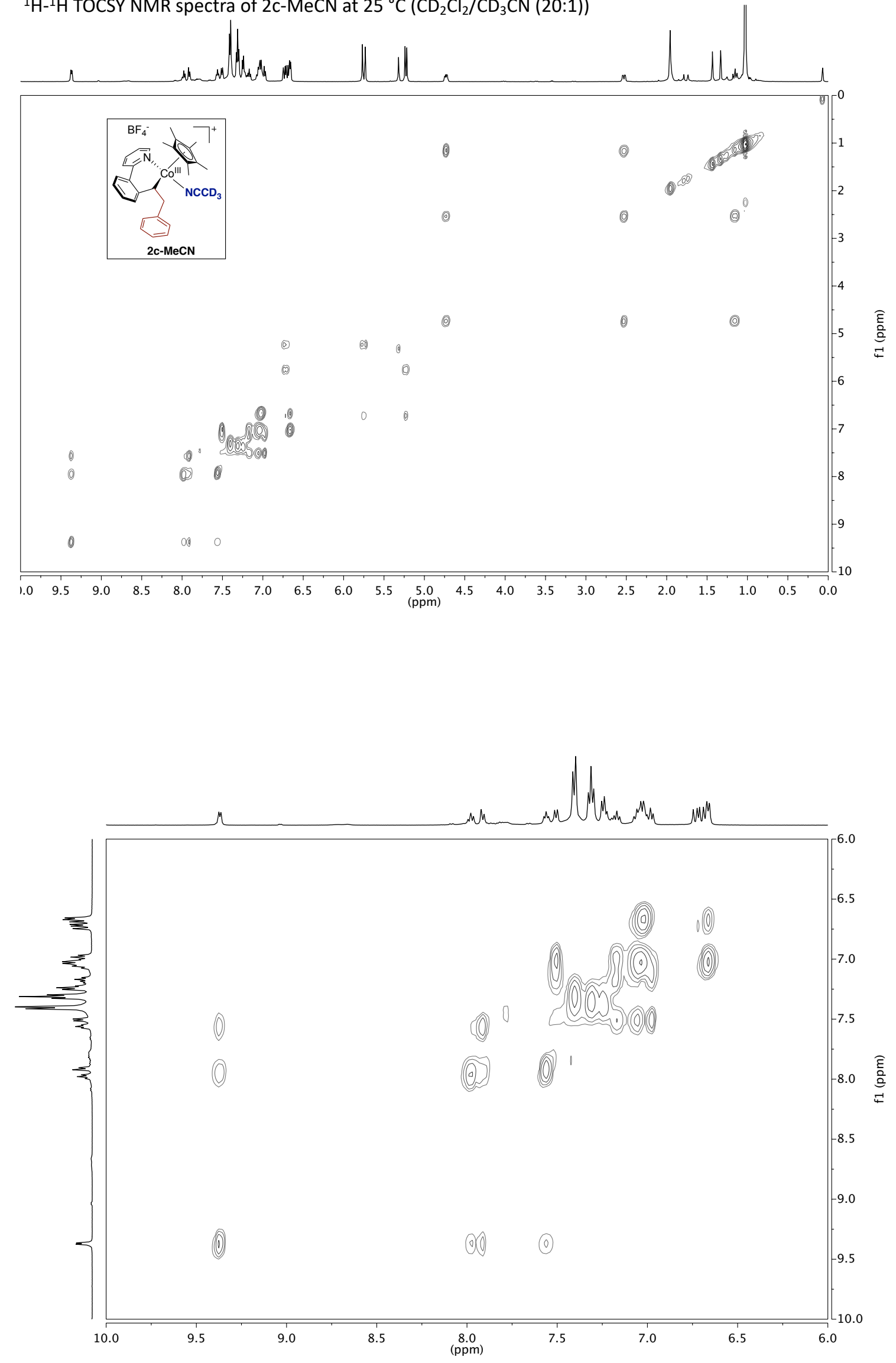

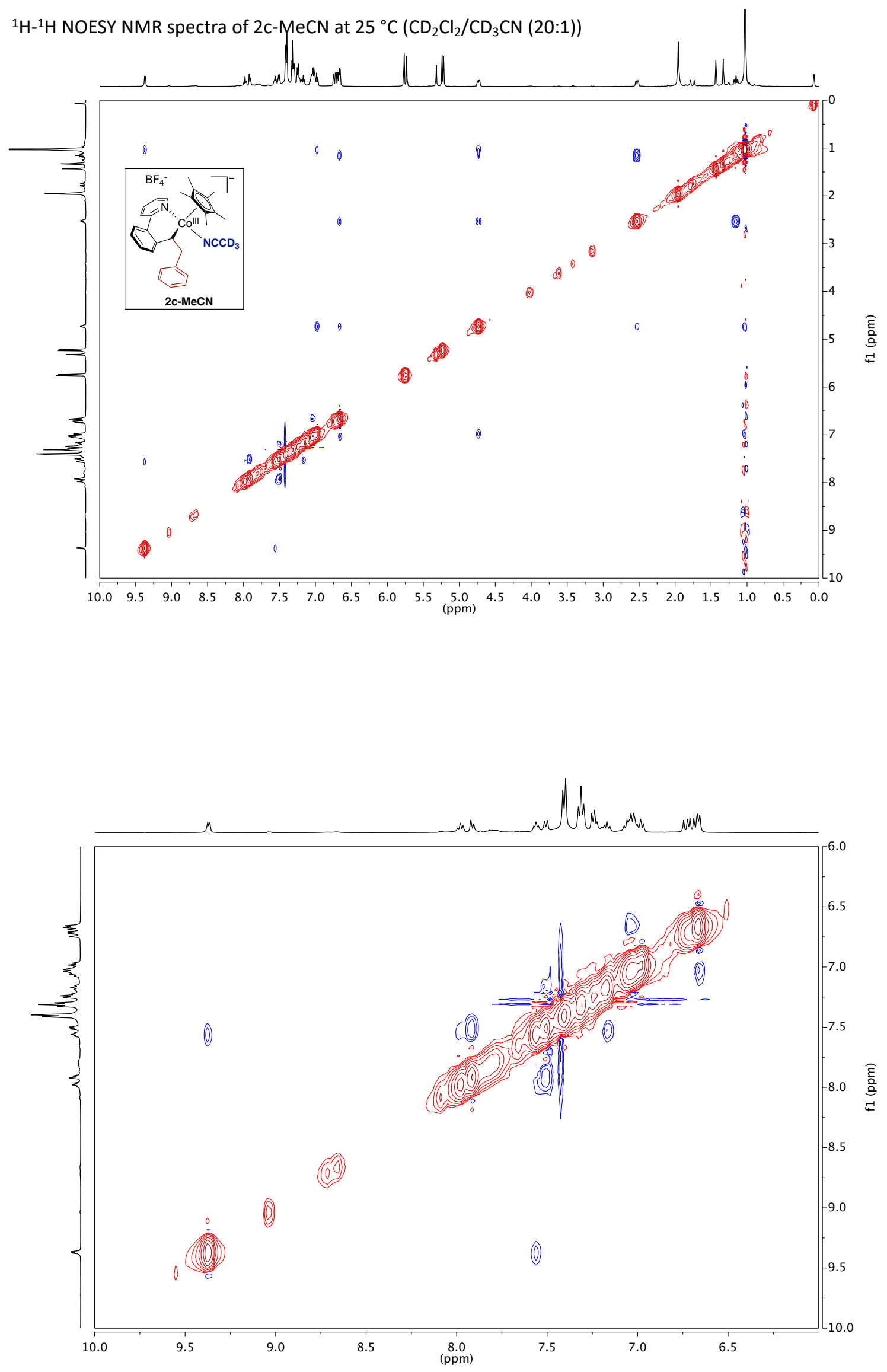

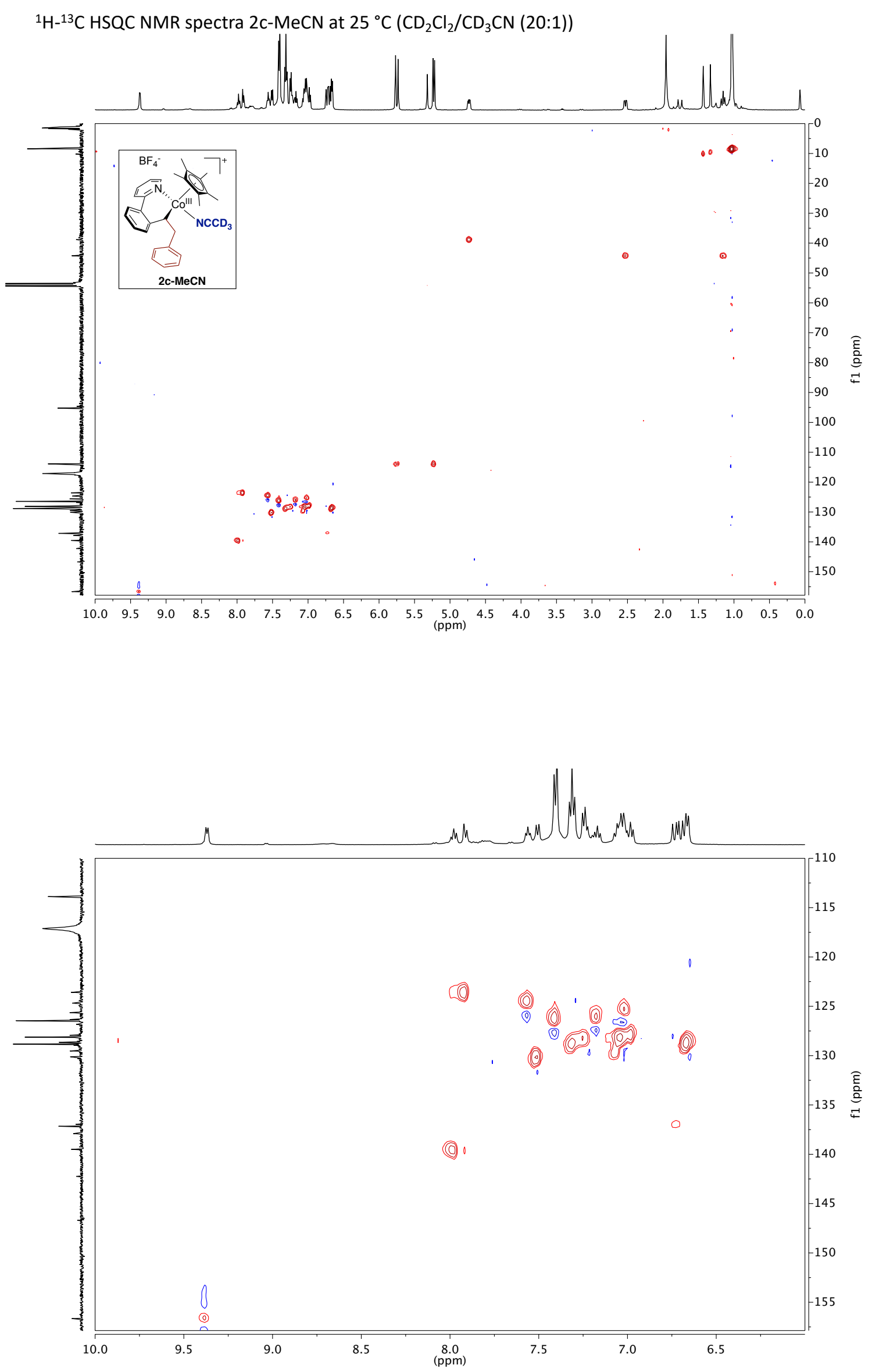
${ }^{1} \mathrm{H}-{ }^{13} \mathrm{C}$ HMBC NMR spectra of $2 \mathrm{C}-\mathrm{MeCN}$ at $25{ }^{\circ} \mathrm{C}\left(\mathrm{CD}_{2} \mathrm{Cl}_{2} / \mathrm{CD}_{3} \mathrm{CN}(20: 1)\right)$
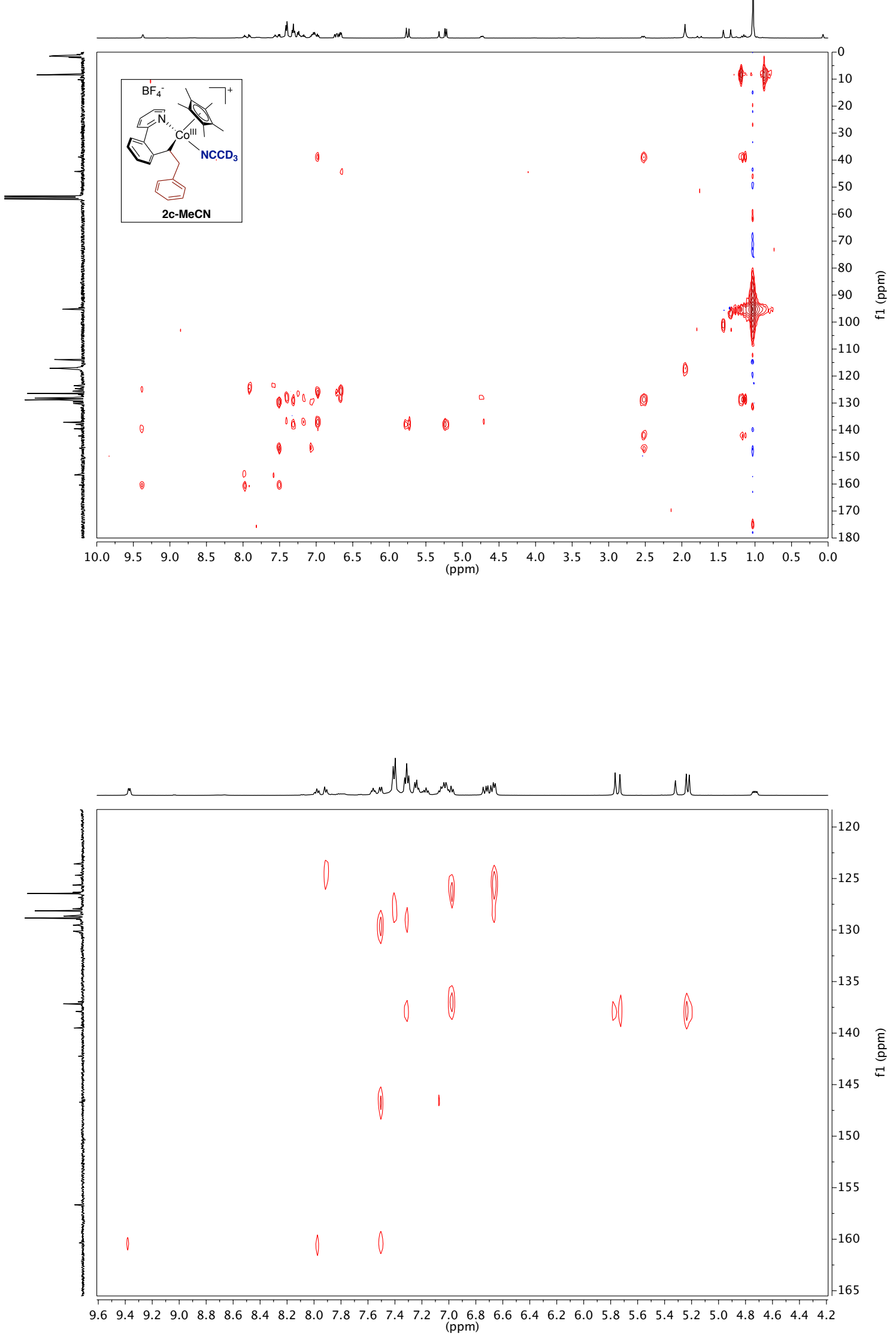
${ }^{19} \mathrm{~F}$ NMR spectra of $2 \mathrm{c}-\mathrm{MeCN}$ at $25{ }^{\circ} \mathrm{C}\left(\mathrm{CD}_{2} \mathrm{Cl}_{2} / \mathrm{CD}_{3} \mathrm{CN}(20: 1)\right)$

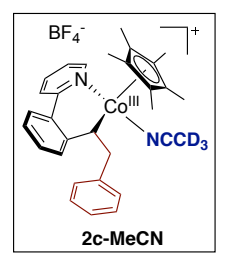

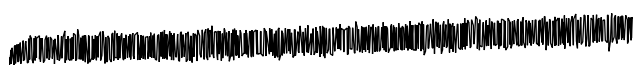

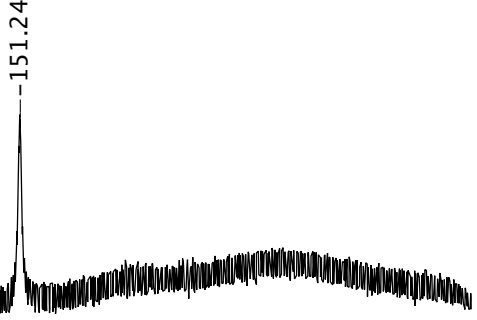

30

10

$10-30$

$-90($ ppm) -110

$-130$

$\begin{array}{llllll}\mid & \mid & \mid & \mid & \mid & \mid \\ -150 & -170 & -190 & -210 & -231\end{array}$ 


\subsection{NMR Characterization of complex $2 d$}

${ }^{1} \mathrm{H}$ NMR spectra of $2 \mathrm{~d}$ at $25^{\circ} \mathrm{C}\left(\mathrm{CD}_{2} \mathrm{Cl}_{2}\right)$
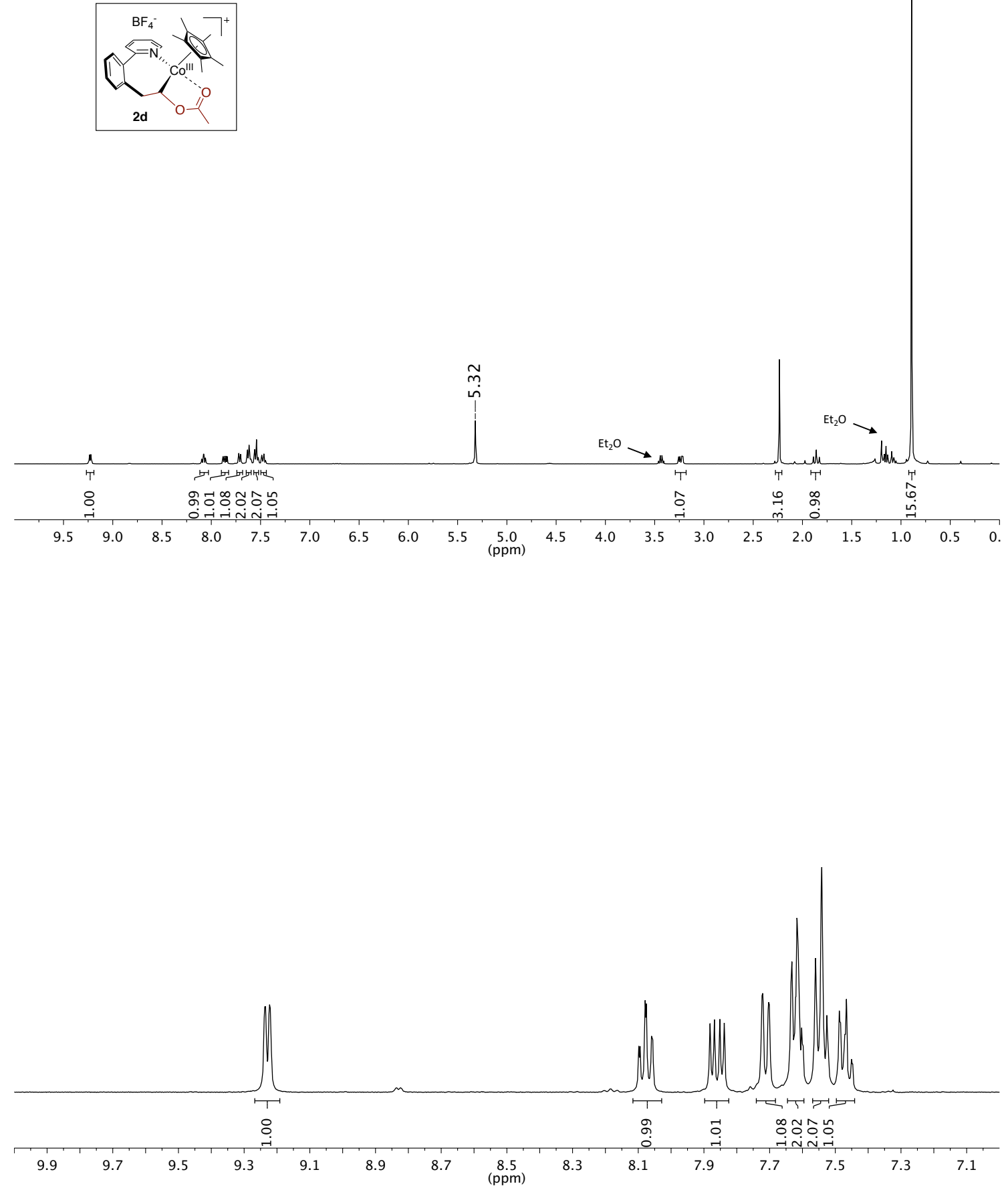
${ }^{13} \mathrm{C}$ NMR spectra of $2 \mathrm{~d}$ at $25^{\circ} \mathrm{C}\left(\mathrm{CD}_{2} \mathrm{Cl}_{2}\right)$
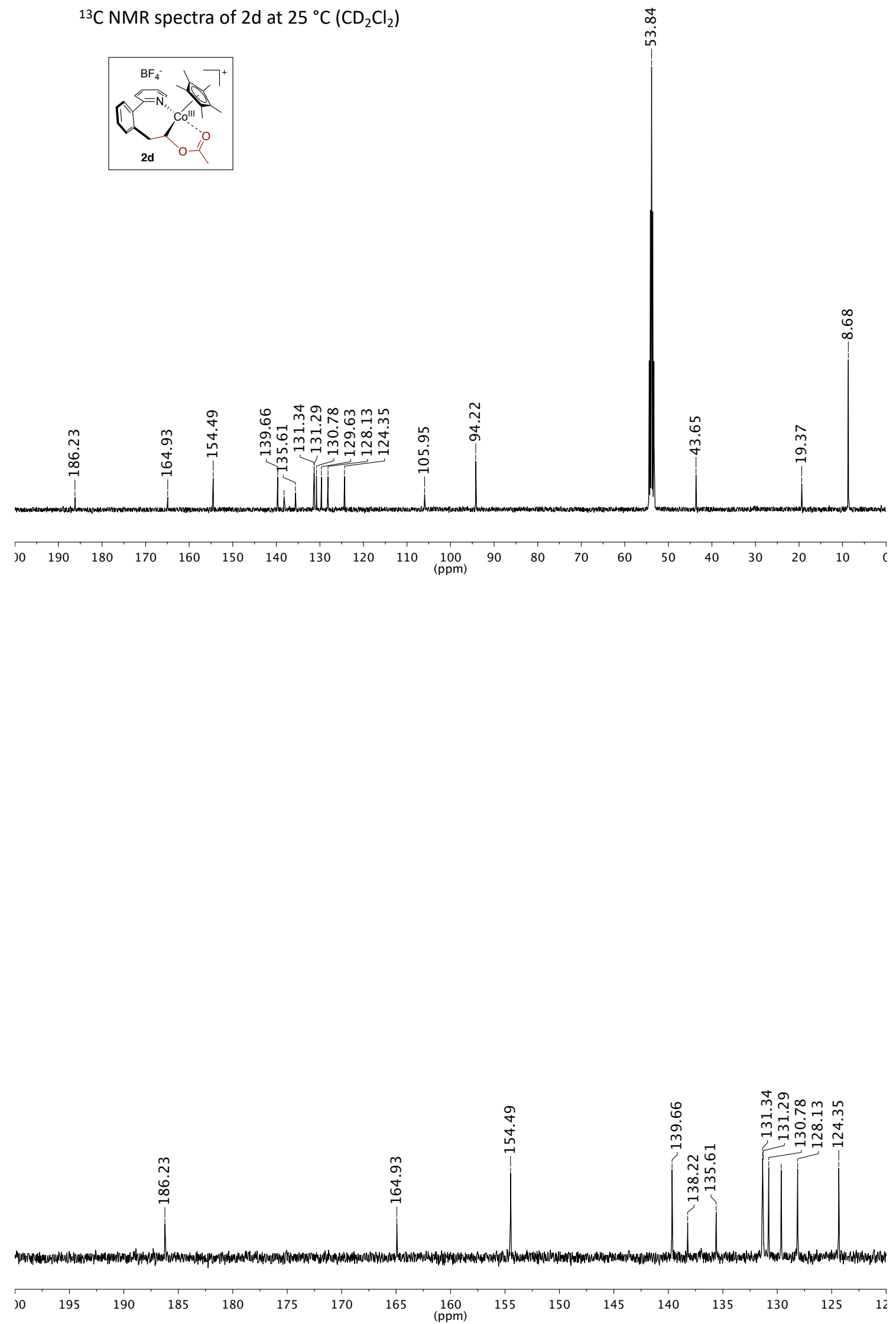

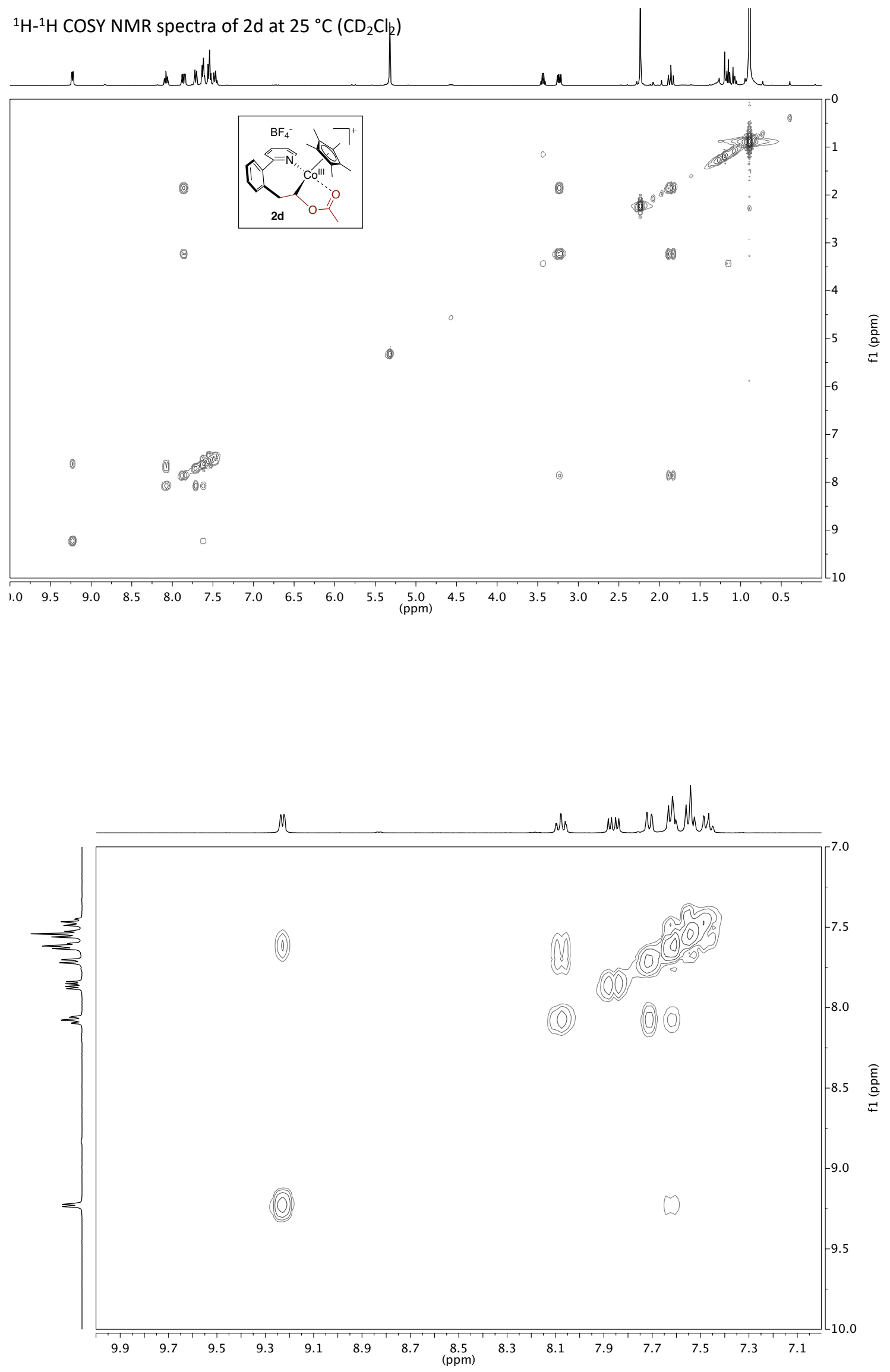

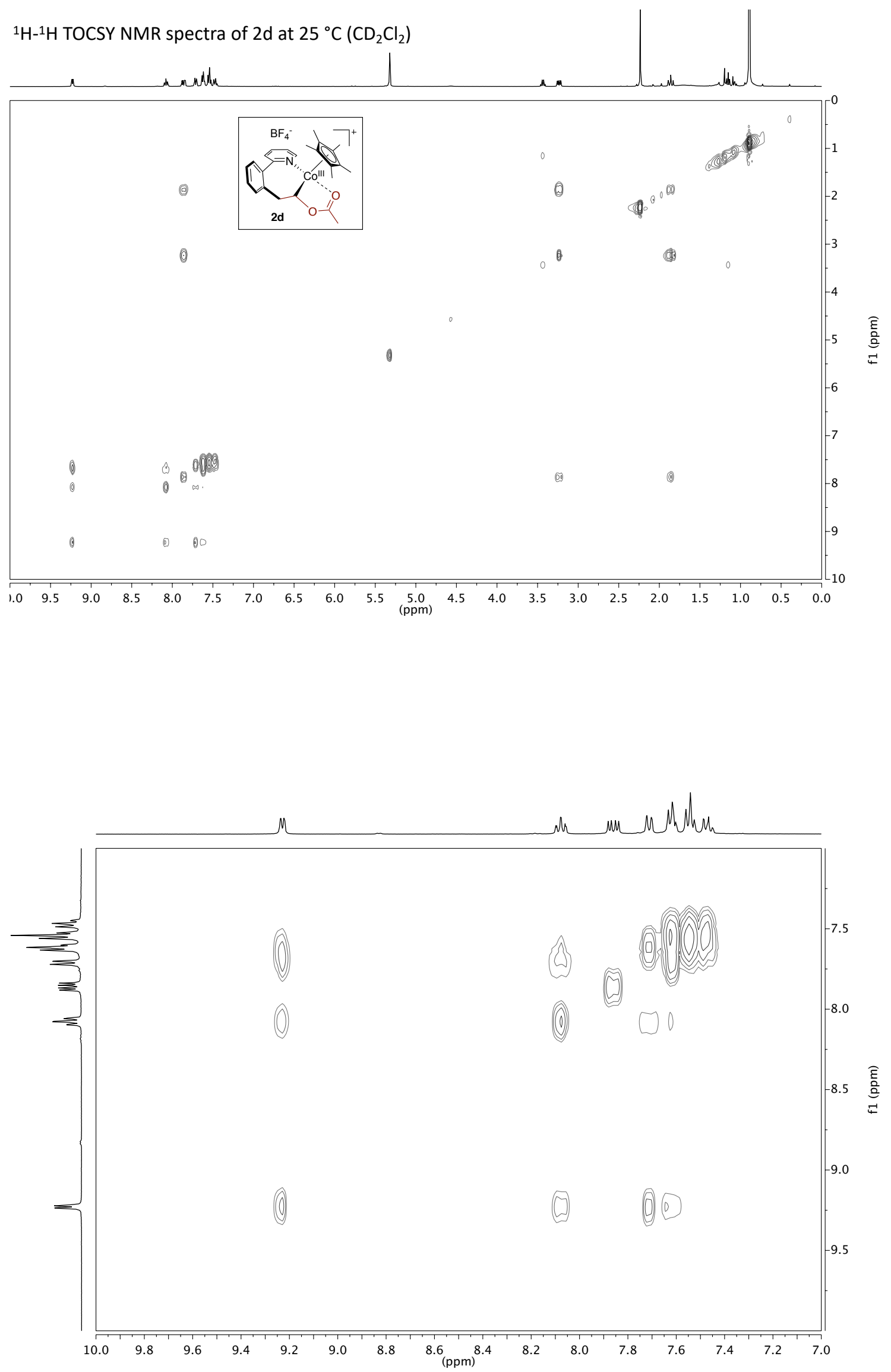

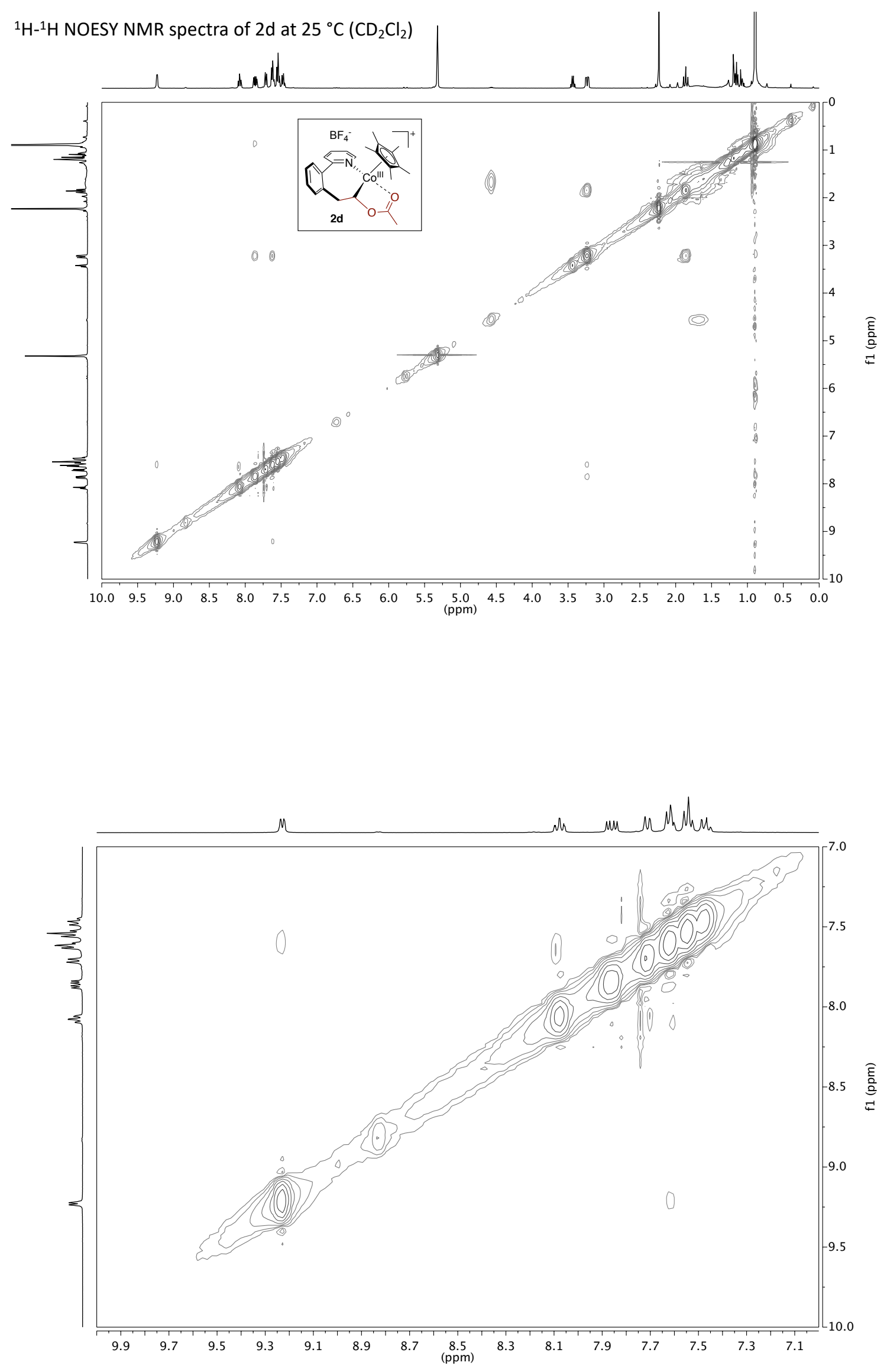

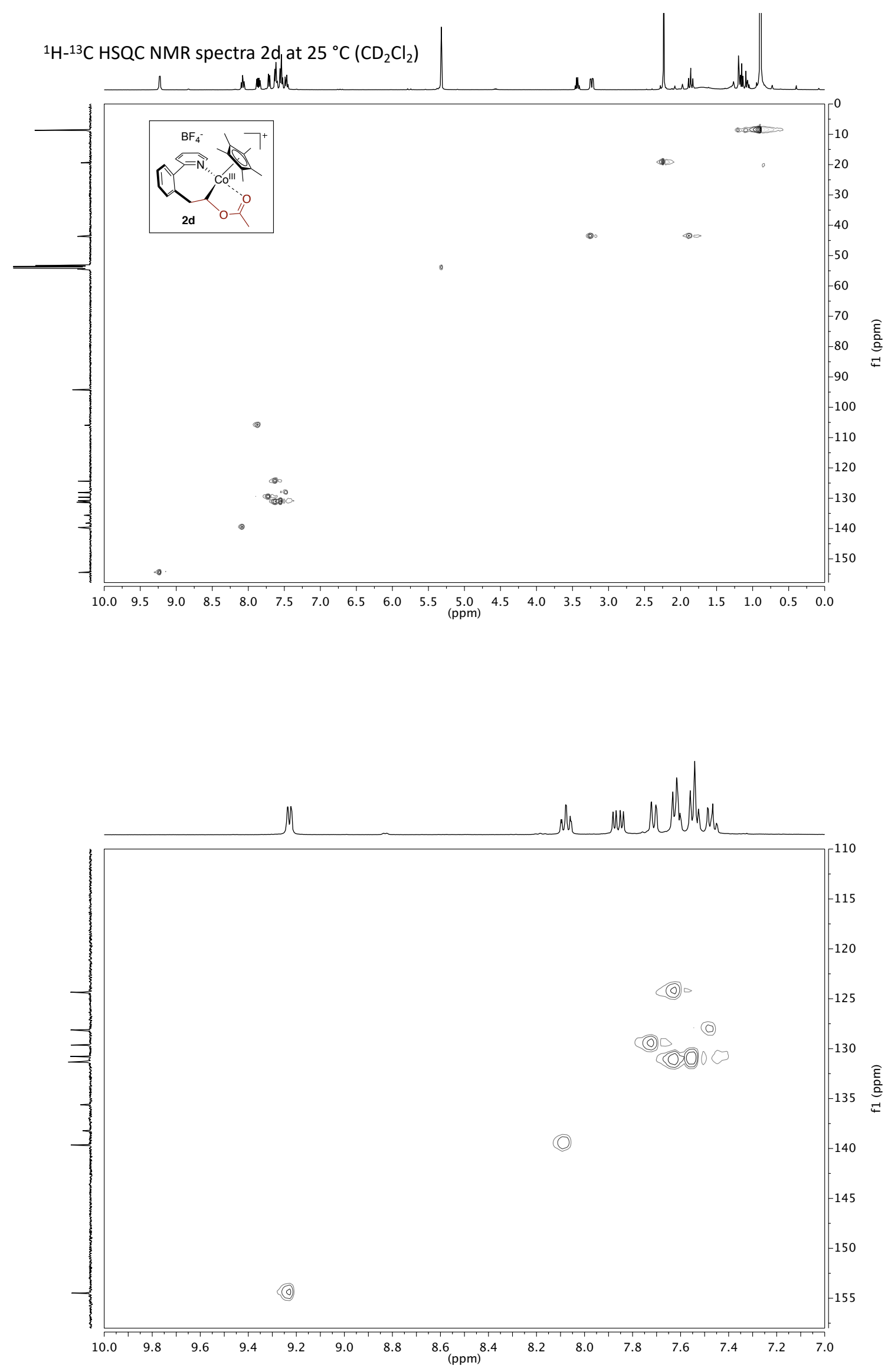

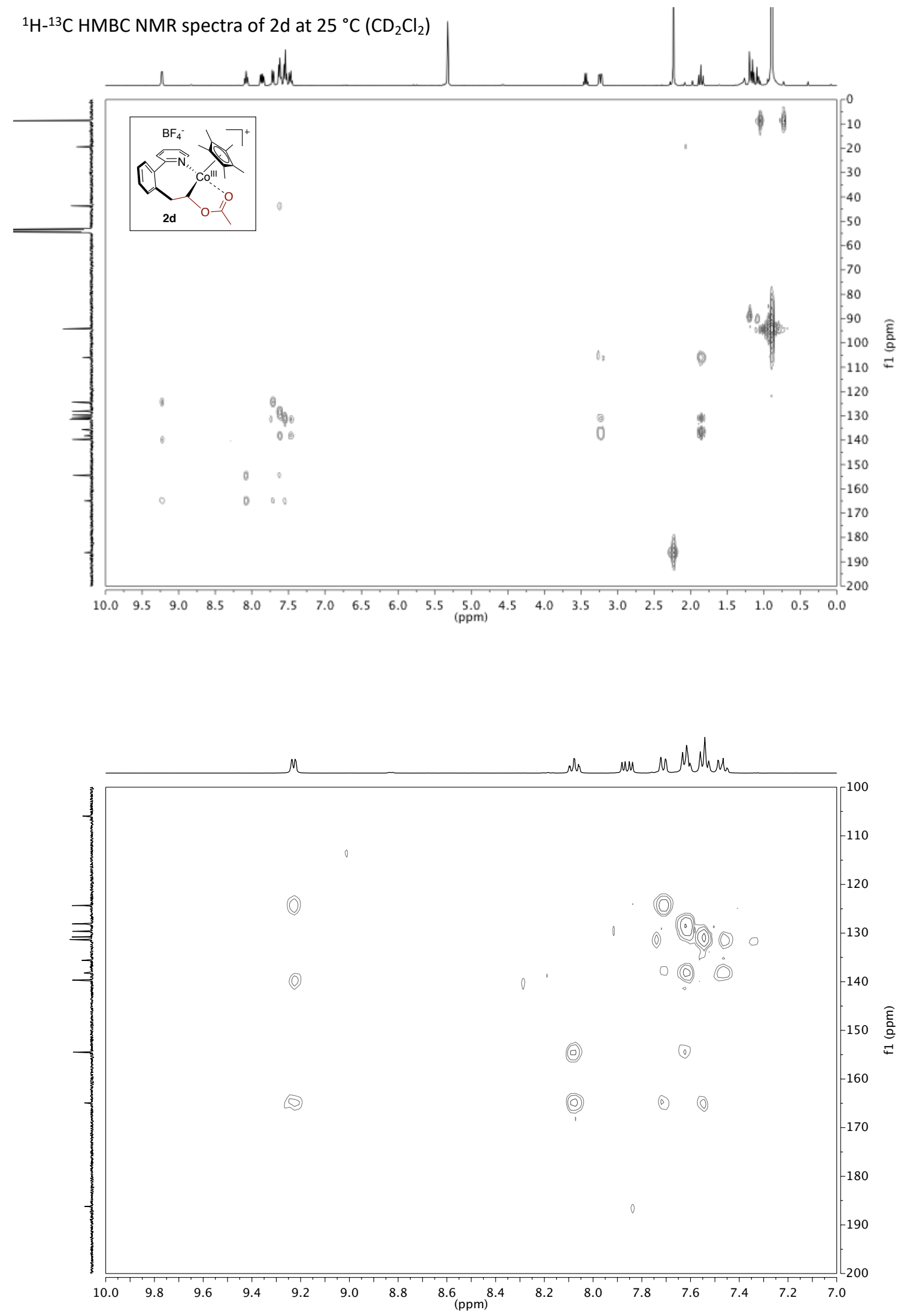
${ }^{19} \mathrm{~F}$ NMR spectra of $2 \mathrm{~d}$ at $25^{\circ} \mathrm{C}\left(\mathrm{CD}_{2} \mathrm{Cl}_{2}\right)$
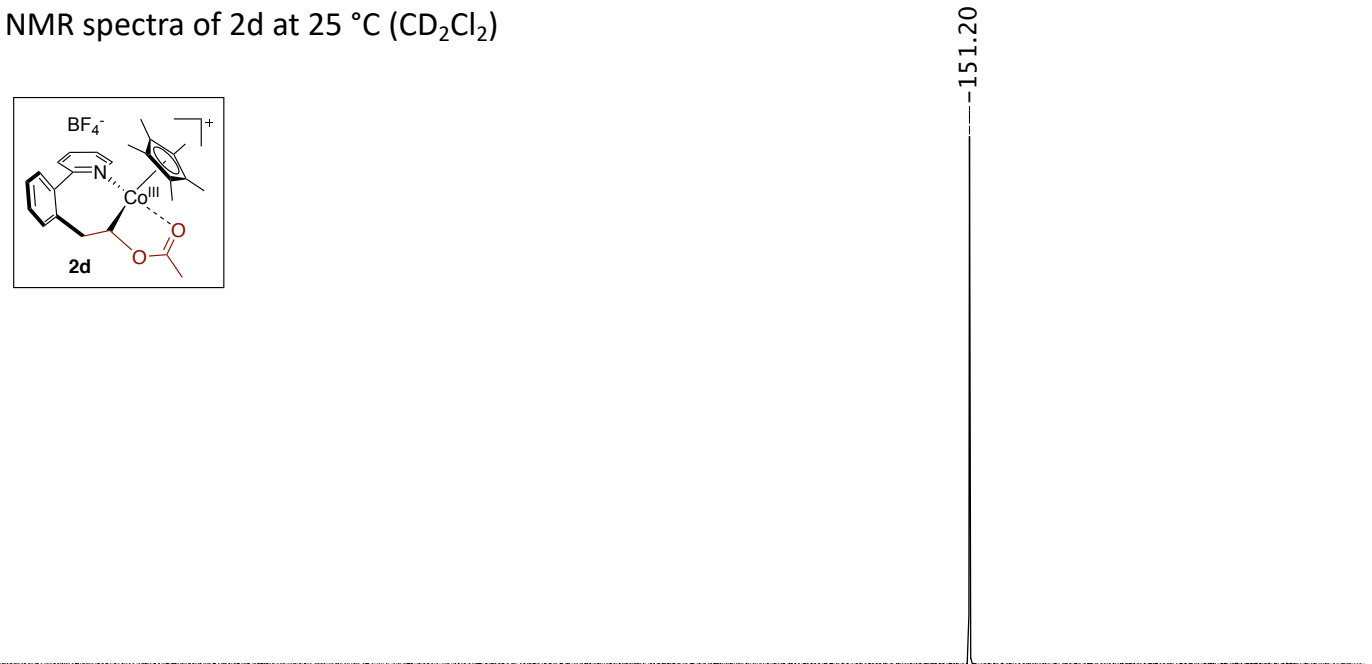

\begin{tabular}{llllllllllllllllllllllll}
\hline 0 & 0 & -10 & -20 & -30 & -40 & -50 & -60 & -70 & -80 & -90 & -100 & -110 & -120 & -130 & -140 & -150 & -160 & -170 & -180 & -190 & -200 & -21
\end{tabular} 